\title{
Designing of Nanomaterials-Based Enzymatic Biosensors: Synthesis, Properties, and Applications
}

\author{
Francisco T. T. Cavalcante ${ }^{1}\left(\right.$, Italo R. de A. Falcão ${ }^{2}$, José E. da S. Souza ${ }^{2}$, Thales G. Rocha ${ }^{2}$, Isamayra G. de Sousa ${ }^{2}$, \\ Antônio L. G. Cavalcante ${ }^{3}$, André L. B. de Oliveira ${ }^{1} \mathbb{D}$, Maria C. M. de Sousa ${ }^{2} \mathbb{D}$ and José C. S. dos Santos ${ }^{1,2, *(\mathbb{D})}$ \\ 1 Departamento de Engenharia Química, Campus do Pici, Universidade Federal do Ceará, Bloco 709, \\ Fortaleza 60455760, CE, Brazil; thalysson.cavalcante13@gmail.com (F.T.T.C.); \\ barros.eng.energias@gmail.com (A.L.B.d.O.) \\ 2 Campus das Auroras, Instituto de Engenharias e Desenvolvimento Sustentável, Universidade da Integração \\ Internacional da Lusofonia Afro-Brasileira, Redenção 62790970, CE, Brazil; italorad7@gmail.com (I.R.d.A.F.); \\ erick@aluno.unilab.edu.br (J.E.d.S.S.); thales@aluno.unilab.edu.br (T.G.R.); isamaayra@gmail.com (I.G.d.S.); \\ mariacristiane@unilab.edu.br (M.C.M.d.S.) \\ 3 Departamento de Química Analítica e Físico-Química, Campus do Pici, Universidade Federal do Ceará, \\ Bloco 940, Fortaleza 60455760, CE, Brazil; luthi2011@gmail.com \\ * Correspondence: jcs@unilab.edu.br; Tel.: +55-85-3332-6109
}

Citation: Cavalcante, F.T.T.; de A. Falcão, I.R.; da S. Souza, J.E.; Rocha, T.G.; de Sousa, I.G.; Cavalcante, A.L.G.; de Oliveira, A.L.B.; de Sousa, M.C.M.; dos Santos, J.C.S. Designing of Nanomaterials-Based Enzymatic Biosensors: Synthesis, Properties, and Applications. Electrochem 2021, 2 , 149-184. https://doi.org/10.3390/ electrochem 2010012

Received: 20 January 2021

Accepted: 5 March 2021

Published: 12 March 2021

Publisher's Note: MDPI stays neutra with regard to jurisdictional claims in published maps and institutional affiliations.

Copyright: (c) 2021 by the authors. Licensee MDPI, Basel, Switzerland. This article is an open access article distributed under the terms and conditions of the Creative Commons Attribution (CC BY) license (https:// creativecommons.org/licenses/by/ $4.0 /)$.
Abstract: Among the many biological entities employed in the development of biosensors, enzymes have attracted the most attention. Nanotechnology has been fostering excellent prospects in the development of enzymatic biosensors, since enzyme immobilization onto conductive nanostructures can improve characteristics that are crucial in biosensor transduction, such as surface-to-volume ratio, signal response, selectivity, sensitivity, conductivity, and biocatalytic activity, among others. These and other advantages of nanomaterial-based enzymatic biosensors are discussed in this work via the compilation of several reports on their applications in different industrial segments. To provide detailed insights into the state of the art of this technology, all the relevant concepts around the topic are discussed, including the properties of enzymes, the mechanisms involved in their immobilization, and the application of different enzyme-derived biosensors and nanomaterials. Finally, there is a discussion around the pressing challenges in this technology, which will be useful for guiding the development of future research in the area.

Keywords: biosensors; nanomaterials; enzyme immobilization

\section{Introduction}

\subsection{Biosensors}

Biosensors are devices that are capable of detecting the presence of specific analytes via their interaction with biological material, such as enzymes, antibodies, and genomes [1-3]. These biological materials act as elements of recognition and can attach to a physicochemical detector that will produce a measurable signal and whose intensity will differ depending on the class of analyte [4,5]. Biosensors must provide fast, specific, and sensitive transduction of biochemical signals [6,7]. With this purpose, many materials have been studied and developed, and in the last couple of years, nanomaterials have received the most attention [8-11].

Biosensors are classified according to the type of transduction performed, which can be of optical, electrochemical, or piezoelectric nature $[12,13]$. There can also be other classifications, such as immunosensors, aptasensors, genosensors, and enzymatic biosensors [14,15]. Usually, carbon is the major element used by biosensors in electroanalysis, as it shows good catalytic properties such as enhanced chemical stability and biocompatibility [16]. In the case of other types of transducers, metals that show more efficient electron transfer capabilities, such as gold, platinum, or palladium, are the preferred sensors for generating these signals $[17,18]$. 
The use of materials with desirable catalytic and sensing characteristics renders biosensors powerful tools in scientific research, such as in the control of water and air pollution [19-21], in biomedical applications (e.g., monitoring of daily glucose levels for diabetic individuals) [22,23], and in the food industry (e.g., measurement of levels of alcohol, carbohydrates, acids, or other compounds in product quality control) [1,24]. Figure 1 shows a summary of the most recurrent applications of biosensors. However, in some on-demand applications for detecting viruses and other particles, electrode-tethered sensors can be more effective, practical, and faster. In Yousef et al. [25], a reagent-free system containing a DNA-antibody complex sensitive to viral particles was studied to develop a rapid test for the presence of SARS-COV-2 viral particles in human saliva (Figure 2). The application of a positive differential potential on the electrode surface induces an electromagnetic force $\left(\mathrm{F}_{\mathrm{e}}\right)$ that attracts the DNA antibody complex, which is negatively charged with the application of a ferrocene redox probe in the structure of the binding DNA. However, a drag force $F_{d}$ contrary to $\mathrm{F}_{\mathrm{e}}$ reduces the attraction speed of the DNA-antibody complex, increasing the time $\tau$ to touch the electrode surface. It was observed that in the presence of viral particles from COVID-19 in the saliva of infected people, the behavior of the current applied to the electrode surface and the time $\tau$ showed significant differences in relation to the presence of other proteins linked to the complex DNA-antibody and the fully unbound protein [25].

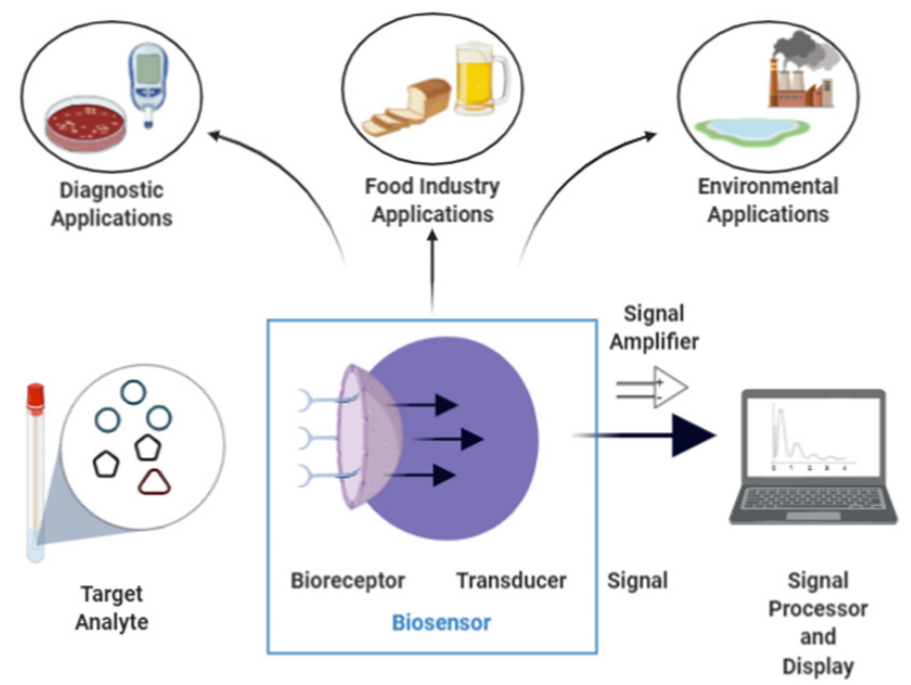

Figure 1. Use of standard biosensors with transducer and signal amplification for data processing.

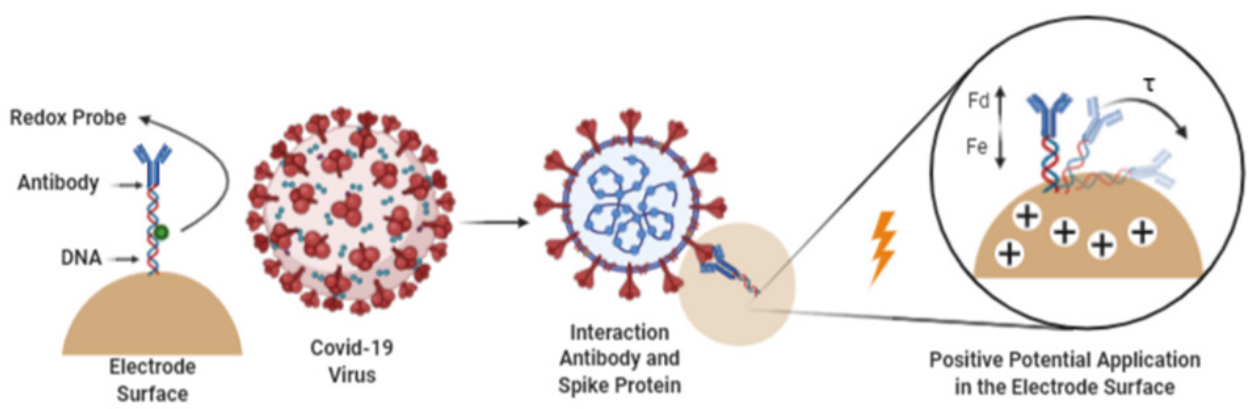

Figure 2. Application of reagent-free DNA-antibody complex sensitive to viral particles by induction and electrochemical attraction for the detection of severe acute respiratory syndrome coronavirus 2 SARS-CoV-2 viruses. More information at Yousef et al. [25].

The sensing properties of biosensors are directly correlated to the properties of the materials used in their bioreceptors and transducers [26]. Several optical transducers can be used in affinity, fluorescence, and surface plasmon resonance (SPR) [27]. Fluorescence detection is one of the methods of optical bioanalysis that presents the greatest sensitivity 
and ease of operation $[28,29]$. In graphene-based biosensors, graphene, which has thin layer of atoms interconnected and in hexagonal conformation within a carbon structure [17,30], has been used in several transduction modes. These biosensors present high electron transfer rates and immobilization capacities [31]. One application of graphene-based nanomaterials as inhibitors in their transducers is the production of fluorescent biosensors due to the high efficiency of their forks and the fact that reduced graphene oxides have fluorescent-quenching characteristics [32,33]. However, some unwanted properties, which are majorly observed in graphene-designed biosensors, should be considered. For example, the different methodologies for synthesizing graphene and its derivatives can impart different properties and functionalities to graphene-based nanomaterials [31]. In addition, some characteristics inherent in the graphene structure can also affect the selectivity and accuracy of graphene-deriving biosensors, such as the number of functional groups in the nanotube, the oxidation state of graphene, and the number of layers in the molecule [31-35].

In comparison to other transducers, biosensors with electrochemical transduction properties can guarantee good advantages for both commercial and research purposes, such as low cost, high sensitivity, and ease of production in reduced form for point-of-care (POC) utilization [27]. As an example of common electrochemical biosensors, we can cite microbial sensors, which can be used to detect biotoxicity levels by using biofilms during an extracellular electron transfer [36,37]. In addition to these advantages, the use of microbial electrochemical sensors allows for online monitoring in real time, self-feeding routine as fuel cells, and the generation of electrical signals without the need for additional transducers [37-39].

Electrochemical immunosensors are also widely used in the detection of pathogens [40] and heavy metals [41] in food by combining the electrochemical properties of these substances and their biomolecule recognition capability [42,43]. However, despite their preparation being relatively easy, the efficiency of the immobilization of antibodies onto the electrode surfaces remains the greatest challenge for avoiding biomolecule denaturation $[43,44]$.

Another important classification of biosensors is made based on the principles of their biorecognition ability, such as catalytic biosensors [27,45,46]. Enzyme-based biosensors are the most widely used in scientific research [47], which is mainly due to the high catalytic power of enzymes, apart from their also high specificity and catalytic activity under mild reaction conditions [48,49]. In addition, the immobilization of enzymes for the obtainment of biosensors is highly recommended, as the practice improves enzyme stability and facilitates the recovery of their catalytic activity and their separation from the product, enabling enzyme recycling and reuse [16,50]. For instance, the literature reports that the optimum conditions under which alcohol oxidase should be immobilized onto platinum electrodes is at temperatures of $35-40{ }^{\circ} \mathrm{C}$ and at $\mathrm{pHs}$ of between 8.6 and 9.2 [19,51]. Within this range, biosensor responses can be successfully reproduced, and there is improved sensitivity $[19,52,53]$.

\subsection{Nanomaterials}

Nanotechnology is a highly interdisciplinary science whose knowledge stems from physics, chemistry, biology, biochemistry, material science, and other engineering branches [54-75]. The science specifically focuses on the study and development of new functional materials, devices, and systems, all at the nanometric scale [58-60]. By definition, nanomaterials have at least one critical dimension of less than $100 \mathrm{~nm}$ [67,72]. They are usually considerably more active than their bulk counterparts and can offer unique properties, such as high surface-to-volume ratio, increased electrical conductivity, exceptional magnetic properties, and greater catalytic activity $[8,14,63]$. The large surface area and the relatively ease of modification by various functional groups translates into efficient biomolecule immobilization, deeming them highly desirable in biosensing applications [53-55]. Over the past few decades, nanostructured materials have considerably changed the analytical and bioanalytical sciences [75]. Nanomaterials have been showing a fundamental role in the expansion of this science to the most diverse industrial fields, 
such as fuel, energy storage, energy conversion, nanocatalysis, integrated catalysis, industrial waste treatment, biomedicine, food, and bioengineering, among others [61,62,75-88] (Figure 3).

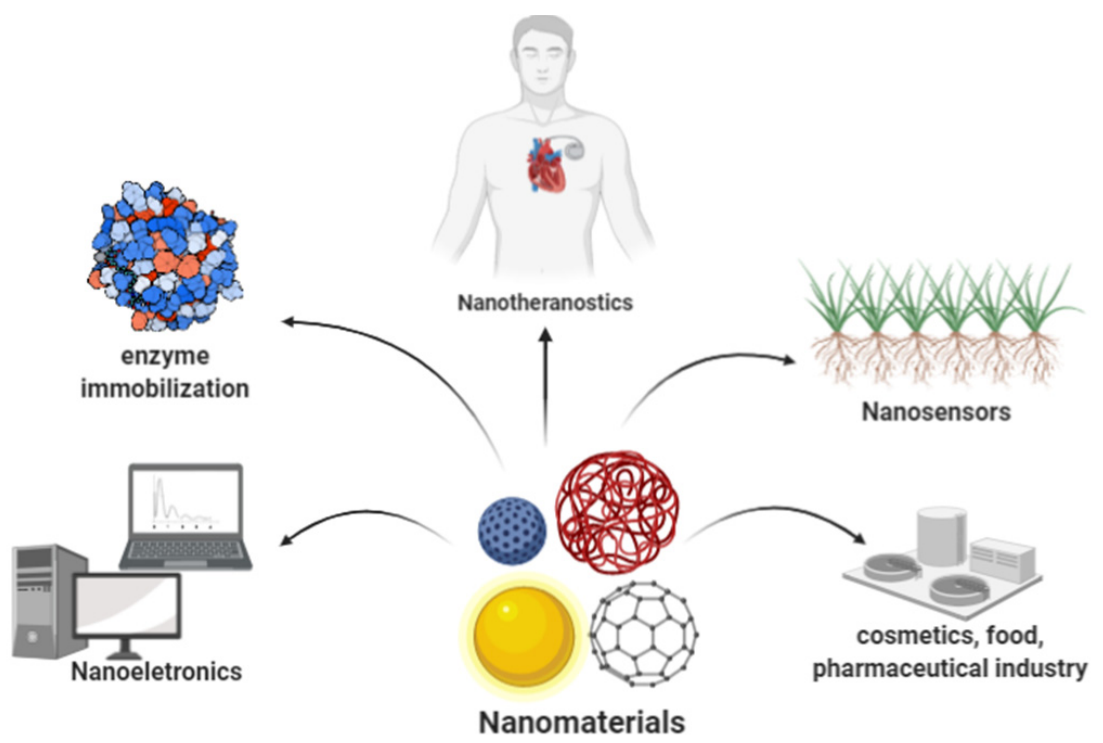

Figure 3. The several applications of nanomaterials.

Among organic nanomaterials, nanotubes stand out due to their high mechanical resistance and capillarity, and their unique electronic structure [73]. In turn, within the inorganic class of nanomaterials, quantum dots are seen as a promising subdivision, given their high applicability in the development of transistors, solar cells, LEDs, quantum computing, among others, all owing to their great optical and electrical properties [74].

The versatility of nanomaterials is attributed to their nanoscale structure, which presents unique chemical, optical, electronic, and mechanical properties [89,90]. It is also important to highlight that the synthesis of any given nanomaterial depends mainly on its end purpose. For example, in the production of paving materials, high resistance to load is necessary. One way to improve these materials is to introduce polymers modified with binders during their production, which can serve as reinforcement material [91,92].

Driven by the potential versatility of nanomaterials and their numerous applications, new fields of study in the area have emerged. The following discussion will focus on the different research trends in the topic of nanomaterials, based on their application versatility and on the number of related publications on scientific databases. For example, in nanomedicine, these structures are already being used for developing surgical nanomaterials, biological devices, and nanoelectronic biosensors, among other possible future applications in molecular nanotechnology, such as biologically operated machines [93-96]. The central idea is to use nanoscale materials for the diagnosis, monitoring, control, prevention, and treatment of diseases. Nanoteranostic applications involve medicinal uses that combine therapy and diagnosis employing materials on a nanometer scale. As such, many treatment protocols for different diseases have evolved greatly due to the growing ascension of this specific area [97-99]. According to works from the literature, a unique capability of nanoteranostics is the possibility of eliminating malignant tumors and their respective metastases via methods that are less invasive and have higher subcellular precision, which is a characteristic defined by the size of the action zone of the nanoparticles in use [100-102].

Enzymatic catalysis has evolved over the years, and consequently, the need to develop new protocols for the synthesis of heterogeneous solid supports has emerged. To this end, nanomaterials are useful as supports in enzyme immobilization, and in most cases, they can enhance several enzymatic properties, conferring to them increased activity, thermal stability, and $\mathrm{pH}$ resistance [103]. The use of nanomaterials as a support for immobilizing 
enzymes has already been proved to improve several properties of the enzymes involved in these processes [50,103-105]. The main factors considered to deem an immobilization protocol efficient are improvements to enzyme activity, selectivity, stability, specificity, and resistance to inhibitors, among others. Xing et al. [106] proposed a lipase B from Candida antarctica immobilization strategy onto magnetic nanoparticles modified with APTES (3aminopropyltriethoxysilane) and activated with glutaraldehyde. These biocatalysts, when used in kinetic resolution reactions, generated a product with an enantiomeric excess higher than $99 \%$. When compared to the result obtained with the free enzyme, the difference is readily noticeable, confirming the improvement caused by immobilizing the enzyme to the support and its later reuse, which is impracticable in the case of free enzymes [106].

The gradual and unsustainable exploitation of the environment has encouraged researchers from the food industry to also explore new tools to increase production while still observing the pillars of sustainability [107]. The industry has been identifying and developing potential applications of nanomaterials in the field for decades aiming at optimizing production [108]. These materials have been currently applied to developing new foods and ingredients, improving food safety, strengthening quality control, and acting as biosensors in contaminated or spoiled food [107-110]. Under this perspective, Hosseini et al. [111] structured a colorimetric and chemiluminescent method mirrored in parameters conjugated with AuNPs to detect aflatoxin B1 (AFB1), which is based on the interactions of gold nanoparticles (AuNPs) with an aptamer. Chemiluminescence is used to increase the catalytic activity of the reaction and also to improve the detection limit. The process of aggregating AuNPs induced the desorption of the AFB1 binding aptamer from the surface of AuNPs. As a result of this interaction, the solution undergoes a color change in AuNPs, which shift from red to purple. In this way, the content of the aflatoxin $\mathrm{B} 1$ present is calculated within a quantification range (80 to $270 \mathrm{nM}$ ). Compared to the traditional detection of aflatoxin B1, this method can be said to be more sensitive and selective, as well as simpler [111].

The cosmetic industry has also been currently investing in new technological approaches to further improve its products. Cosmetics belong to a market recognized by notable technological advances and the presence of a myriad of loyal consumers [112]. However, for products to be deemed effective and safe, it is necessary that they follow specific regulations, which span different stages across all production protocols [112,113]. In this sense, nanomaterials have become a viable and competitive alternative for achieving the results desired by the industry and its consumers via the use of small aggregations of active compounds aimed at the improvement of product quality [113]. Modern applications of nanomaterials in cosmetics involve the use of nanocrystals, microemulsions, nanoemulsions, fullerenes and dendrimers, nanopigments, and nanocapsules, among others [114]. Many cosmetic protocols and formulations require precise, accurate, and judicious analyses, and their characterization, quantification, and separation are essential for the safe obtainment of the final product. Cao et al. [115] developed an optimized protocol that includes the separation, quantification, and characterization of gold nanomaterials in commercially available cosmetic creams, which can assist regulatory agencies in cosmetics analysis. According to their protocol, the total amount of gold in creams was first quantified by mass spectrometry with inductively coupled plasma (ICP-MS) following wet digestion. In sequence, gold nanomaterials were separated from other cosmetic ingredients by solvent extraction. Next, analyses of physical-chemical parameters and preliminary cytotoxicity tests on the gold nanomaterials extracted were performed, which is an essential step for evaluating the safety of engineered nanomaterials in cosmetics. Their morphology was also analyzed by several electron microscopy and atomic force techniques, ensuring good nanomaterial characterization [115].

The electronic development sector is another area that has seen exponential growth, which has been driven by the rise of the communication market achieved by a robust and well-structured marketing strategy in digital media [116]. As a result, the nanoelectronic science emerged, which aims to develop electronic components in the nano-order of 
magnitude. The evolution of nanoelectronics was propelled by the need to improve a wide array of electronic components [117-119]. In addition, in the wearable electronics industry, the enormous current demands have been generating flexible and extensible devices that can be easily integrated into the skin or to soft and curvy human clothing [115-120]. Currently, nanomaterials have been enabling these properties in clothing that are marketed to the general public. In this specific field, the 1D nanostructures used have showed better mechanical elasticity than their equivalent larger materials or ball-like nanoparticles [120].

Nanomaterials have also been offering excellent opportunities for the construction of new electrochemical sensors. This was due to the possibility of working with this type of sensors in reaction environments with high resistivities, such as in organic solvents or in solutions with low levels of support electrolytes; for example, this feature can be successfully used for biosensing applications [121-123].

Thus, nanomaterials can clearly be presented as potential alternatives in the advancement of various industrial sectors, apart from also being capable of fostering other scientific developments. However, there are some disadvantages and challenges that still limit a wider use of nanomaterials. One of the main limitations observed is the difficult optimization of the analyses of materials and the testing of the protocols for further applications. Many current scientific advances are restricted by several bureaucratic measures regarding their reliability $[124,125]$. In addition, a clear example of a risk involved in research labs is the inhalation of dust in the case of accidental spillage or dispersion of nanomaterials. In this case, the use of PPE (personal protective equipment) does not provide enough protection, as nanomaterials are too small to be retained by these. Regarding the medical applications of nanomaterials, despite the numerous advantages listed previously, their toxic effects cannot be ignored [126]. As for the nanoimmobilization of enzymes, aspects linked to the cost of production and large-scale applications have challenged several researchers. However, the development of more robust nanomaterials has shown to be a potential and effective solution to these adversities [124].

In summary, nanomaterials are promising alternatives for facing and overcoming some of the environmental challenges of the 21st century. Therefore, their use remains a potential alternative in the advancement of several subsectors of nanotechnology. It is noteworthy that the versatility of these materials is one of their most praised attributes, which is complemented by their unique physical and chemical properties. Given this versatility, nanomaterials add considerable value to the research on the development of sensors, biosensors, and nanobiosensors [127]. Nanobiosensors appear as feasible alternatives in medical therapies and in the diagnosis of several diseases. It is also worth mentioning their role in several other medic applications, such as the monitoring of tumor and glucose levels, the evaluation of cardiovascular diseases, controlled drug release, microbiology and virology, detection, and the functionality of nucleic acids, among others [128]. The next section will address the use of nanomaterials in the synthesis of biosensors and their various related applications.

\section{Nanomaterial-Based Biosensors}

Nanobiosensors have become one of the main tools in the field of disease diagnosis, especially in the last decade $[10,129,130]$. Several industries have since incorporated nanomaterials in the production of biosensors that present refined sensitivity, selectivity, and specificity $[131,132]$. Industries such as the medical, food, electronic, enzymatic, and several others are the main ones responsible for their popularization. In this sense, the applications of several biosensors, according to the volume of publications across scientific databases, are discussed in the aforementioned sequence.

Four main types of nanomaterials can be highlighted due to their versatility: gold nanoparticles, graphene, carbon nanotubes, and photonic crystals [133-135]. Table 1 shows the nanomaterials most widely used in biosensing applications. Due to the growing demand for increasingly versatile and high value-added nanomaterials, universities, insti- 
tutes, and laboratories have long been dedicating their research efforts to the improvement of nanobiosensor design technologies [136].

Table 1. Nanomaterial-based biosensors for different applications.

\begin{tabular}{|c|c|c|c|}
\hline Nature & Nanomaterial & Applications & Reference \\
\hline Organic & Carbon nanotubes & Biomedical & [137] \\
\hline Hybrid & GR-MWNTs / AuNP (1) & Biomedical & [138] \\
\hline Hybrid & $\mathrm{Au} @ \mathrm{PDMPAHCl}{ }^{(2)}$ & Biomedical & [139] \\
\hline Inorganic & $\mathrm{Fe}_{3} \mathrm{O}_{4}$ & Biomedical & [140] \\
\hline Inorganic & $\mathrm{Fe}_{3} \mathrm{O}_{4}$-silica NPs ${ }^{(3)}$ & Biomedical & [141] \\
\hline Hybrid & CS/AuNPs-GNs ${ }^{(4)}$ & $\begin{array}{c}\text { Food and } \\
\text { environmental }\end{array}$ & [142] \\
\hline Inorganic & Ceria nanospheres & Food & [143] \\
\hline Hybrid & MNP-PAMAM-PtNP/rGO-CMC (5) & Food & [144] \\
\hline Organic & $\mathrm{MnO}_{2}$ modified MWCNTs * & Biomedical & [145] \\
\hline Organic & Tobacco mosaic virus & Biomedical & [146] \\
\hline Hybrid & Carbon ceramic & Biomedical & [147] \\
\hline Organic & poly(l-aspartic acid)/MWCNT * & Food & [148] \\
\hline Hybrid & Chi-Gr cry/PB/SPCE ${ }^{(6)}$ & Uric acid detection & [149] \\
\hline Hybrid & Titanim dioxide hybrid & Biomedical & [150] \\
\hline Inorganic & Semiconductorquantum dots & Biomedical & [151] \\
\hline Organic & Carbon black & $\begin{array}{l}\text { Biomedical and } \\
\text { environmental }\end{array}$ & [152] \\
\hline Hybrid & Electrospun nanofibers & Biomedical & [153] \\
\hline
\end{tabular}

(1) Gold nanoparticles prepared at graphene and multi-walled carbon nanotubes; ${ }^{(2)}$ Core-shell gold nanoparticles stabilized with poly(3-dimethylammonium-1-propyne hydrochloride); (3) Magnetic nanoparticles-silica core shell; ${ }^{(4)}$ Chitosan/gold nanoparticle-graphene nanosheets; ${ }^{(5)}$ Poly(dopamine)-modified magnetic nanoparticles coated with four-generation ethylenediamine and core polyamidoamine G-4 dendrimers, all decorated with platinum nanoparticles on the surface of glassy carbon electrodes coated with graphene oxide and carboxymethylcellulose; ${ }^{(6)}$ Porous cryogel platform of graphene-incorporated chitosan on top of a Prussian blue layer electrodeposited on a screen-printed carbon electrode. * Multi-walled carbon nanotubes (MWCNT).

The standard structure of biosensors is a classic system containing three fundamental elements: a bioreceptor, which is responsible for the selectivity of the device, a transducer that translates the physical or chemical change, leading to analyte recognition, and a signal processing unit [154]. The projection stage of the interaction between the biological and the transducer systems is fundamental for method design and possible test protocols for the nanosensor. In this phase, chemistry and computational biochemistry are essential elements to enable greater security to the method and generate considerable savings in reagents, human resources, and time.

Among medical applications, nanobiosensors are viable tools for detecting viruses or bacteria, which can cause potentially deadly diseases. Joshi et al. +developed a biocompatible, economically competitive, reduced graphene oxide (rGO) film. The film was obtained from shellac using a heat treatment (TrGO). After analysis, its relevant structural, chemical, and electrical properties were compared to similar films. After the heat treatment, the rGO (TrGO) film showed good crystallinity, low foil resistance, and high carbon content. From the TrGO, electrochemical immunosensors were produced without labels for the quantitative detection of the H1N1 influenza virus employing electrochemical impedance spectroscopy. These nanosensors exhibited high stability and reproducibility. The detection limits were of 26 and 33 plaque-forming units, respectively, in phosphate-buffered saline and diluted saliva. These low-cost TrGO-based sensors showed great potential as biosensors based on reliable and robust nanomaterials for general clinical applications [155].

Cancer diagnosis has become increasingly precise and selective, but errors are still common. Especially in this specific field, such errors must be minimized and procedures must reach high levels of accuracy. One of the most lethal types of cancer is ovary cancer, which is commonly diagnosed by biomarkers such as CA125, Mucin 1, HE4, and others, 
which may be present in the bloodstream [156]. However, there is a latent need for less expensive, more straightforward, and portable diagnostic tools for the timely diagnosis of ovarian as well as other types of cancer [157,158].

A possible solution is the employment of nanomaterial-based biosensors as tumor markers. In one of their pieces of research, Raghav et al. [159] presented an impedimetric immunosensor for free detection of the CA-125 marker. The CA125 immunosensor was produced using an electrode printed on a screen modified with $\mathrm{Au}-\mathrm{Ag}$ NPs and functionalized with amine, which confers a larger surface area, besides providing the immobilization of antibodies in the correct orientation, that is, the formation of covalent amide bonds across the region antibody Fc. The functionalized immunosensor exhibited a linear response of up to $1-150 \mathrm{IU} / \mathrm{mL}\left(\mathrm{r}^{2}=0.994\right)$. The dynamic range of $1.0-1000 \mathrm{IU} / \mathrm{mL}$ reported in the literature makes it suitable for detecting CA125 without the need for any sample pretreatment, such as dilution, separation, or other adjacent processes. It is noteworthy that no significant interference was noticed from the chemical reagents or the serum proteins present in the blood. Considerable research is still being carried out to study the parameters that govern this linear response in more depth and whether they are dependent on nanoparticle size or on other particular properties of the nanomaterials used [159].

From this perspective, developing new sensing tools to identify tumor cells have evolved significantly due to the pressing need for less invasive and more accurate methods. These biosensors are mainly used to detect specific tumor biomarkers for different types of cancer. The literature already has a vast library of biomarkers but some methods are insufficiently selective. A classic example of a biomarker is the human mucin one protein (MUC1), which is the most common biomarker for monitoring metastatic breast tumors. In the study by Paimard et al. [160], the authors reported on an impedimetric assay for MUC1 identification using a gold nanocomposite with a nanofiber core shell on a multi-walled nanotube (MWCNT) that had been covalently modified with the MUC1 binding aptamer. MUC1 was detected by changing the surface resistance of the synthesized electrode. This nanobiosensor exhibited a high detection limit (LD) of $2.7 \mathrm{nM}$, good stability, and selectivity in the narrow region of $5-115 \mathrm{nM}$ of MUC1. The assay was successfully applied to determine MUC1 in enriched serum samples and yielded satisfactory recoveries [160]. Despite the fact that this work is relatively recent, the laboratory tests were considered significant and indicated the possibility of their use on clinical trials from the first stage of the disease.

In the food industry, nanosensors are promising alternatives to solve several common problems in the sector [161]. The development of "smart tags" based on nanomaterials can evaluate product quality. These labels can interact with gases, microorganisms, and other by-products generated during food decomposition or adverse reactions with the packaging material. Many labels use a color change in the indicators present in the sensors as a means to alert consumers about the quality of a product $[162,163]$. This is in line with the concept of smart packaging (SP), which encompasses any type of container that provides specific functionality beyond their basic function of being a physical barrier between the food product and the surrounding environment [164]. Many packages are currently formulated with nanomaterials that provide improvements to their physical, chemical, and biochemical properties, imparting a longer shelf life for different products.

Practical applications in this area include the work of Faalnouri et al. [162], who developed surface plasma resonance (SPR) nanosensors to detect amoxicillin in milk samples using a molecular printing technique. Laboratory tests have shown that this nanosensor has a low detection limit and a high sensitivity and selectivity for identifying amoxicillin. As this study is very recent, the scientific community awaits for further tests before the product can be commercialized [162]. In addition, Xiang et al. [165] proposed the synthesis of a new nanosensor functionalized with black phosphorene (BP) in two-dimensional layers (2D). The tool was used to detect ochratoxin A (OTA) in grape juice and red wine samples. OTA is a toxic metabolite secreted by species of Aspergillus and Penicillium fungi, and it can cause severe nephrotoxic, immunotoxic, and carcinogenic effects [166]. 
In the literature, short reports on the electrochemical detection of this metabolite using a chemically modified electrode can be found. The BP-modified nanosensor exhibited an excellent linear electrochemical response to OTA in the concentration range of $0.3-10 \mu \mathrm{g} / \mathrm{mL}$, with a detection limit of $0.18 \mu \mathrm{g} / \mathrm{mL}$ under ideal conditions. It was concluded that this electrochemical nanosensor showed good stability, superior anti-fouling property, and excellent sensitivity for OTA detection [165].

In summary, nanomaterials in the preparation and functionalization of biosensors have been proved to be a promising opportunity for solving several problems in the food sector, in agriculture, in applied medicine, in the enzyme preparation industry, among others, all of which are discussed in the next sections [130,167-170].

\section{Enzymes}

It has been observed that nanomaterial-based biosensors have elevated sensitivity and specificity [171]. These characteristics can be improved both by improving their conductivity and via the creation of a layer of nanomaterial on the surface of the transducer, onto where a wide variety of compounds can be immobilized, including biological materials [172,173]. It is important to highlight that materials with a high specific surface, such as $\mathrm{NP}$, can increase the number of bioreceptor units within a reduced volume while still acting as a transduction element [152]. However, the variation in size, shape, and composition of nanoparticles, along with the general instability of their suspensions, can influence reaction performances and response times, potentially causing low reproducibility and negatively affecting their commercial interest [173].

Enzymatic biosensors, on the other hand, show less stability, lower signal intensity, higher cost, and in some cases, they require association with a mediating system [174]. However, they can be highly sensitive and selective [171]. Biomolecules can be immobilized and combined with other materials by surface modification through recombination or the introduction of binders [171]. Enzymatic biosensors are easy to use, sensible to very low concentrations, highly precise, and even when associated with NPS, they show great potential for miniaturization and real-time diagnostic capability, apart from requiring minimal sample preparation and promoting high yields [175].

Enzymes are biocatalysts that facilitate a plethora of reactions in biological systems, apart from being essential entities for sustaining life in several living organisms [176-178]. They are synthesized in animals, vegetables, fungi, and microorganisms [179,180], and their structure is composed of linear chains of amino acids that fold into complex, highly accurate tertiary structures with hydrophobic nuclei surrounded by hydrophilic layers [181,182]. The complexity of their three-dimensional structures provides the chemical environment necessary to catalyze a particular reaction mechanism, and they also present a defined region within their structure, called the active site, where catalysis takes place [183,184].

Several chemical-based transformation processes still employed in various industrial sectors show many disadvantages, from both a commercial and an environmental perspective, such as low yields, very high temperature, pressure, and acidity or alkalinity requirements, and high costs [185]. The environmental and economic impact imparted by using enzymes is greatly reduced by their potential of creation of more active variants than those found in nature [186]. Enzyme-assisted catalytic processes are highly efficient and advantageous due to the possibility of operation under mild conditions of reaction, high selectivity and specificity, lower environmental and physiological toxicity, and reduced costs and waste generation, all of which leads to more optimized production routes [187-193].

It is important to highlight that enzymes, when used in their free form, present limitations relating to their stability, efficiency, and specificity. Most of them are soluble in water, which makes it difficult to recover and reuse them [194]. Despite its excellent performance potential, industrial applications were made impossible due to these undesirable characteristics [195,196]. In this scenario, immobilization techniques stand out as alternatives to overcome these limitations, since they can offer better stability, increased activity and 
selectivity, excellent resistance, improvements in product separation and purification, and the possibility of enzyme reuse, rendering processes increasingly efficient [192-206].

\section{Enzyme Immobilization}

Enzymatic immobilization is based on the confinement of enzyme molecules on the surface of a reliable support that is different from that in which the substrate or products are present [202-209]. In contrast with their solubilized form, immobilized enzymes provide a large enzyme to substrate ratio, efficient digestion, and secure handling, in addition to showing more significant activity and the possibility of reuse for several cycles [197,210-213]. The stability of free enzymes is mainly dictated by its intrinsic structure, while the stability of their immobilized counterparts is highly dependent on several other factors, as shown in Figure 4. These factors are responsible for the stability of immobilized enzymes under different temperatures and storage conditions. The experimental variables can be expected to increase or decrease during the immobilization process [214-217].

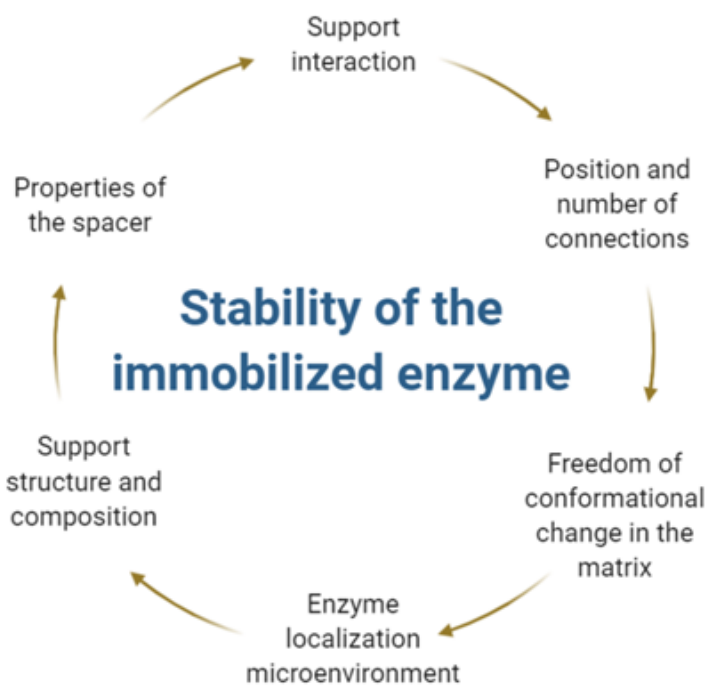

Figure 4. Determining factors for the stability of immobilized enzymes.

According to the modes of interaction between enzymes and supports, immobilization methods can be classified into physical or chemical methods, as shown in the scheme in Figure $5[180,218]$. Physical methods show weaker monovalent interactions, such as hydrogen bonds, hydrophobic interactions, van der Waals forces, affinity or ionic bonding of enzymes to the support, or the mechanical containment of enzymes within the support [219-222]. In chemical methods, the formation of covalent bonds occurs from ether, thioether, amide, or carbamate bonds between the enzyme and the support material [223]. Each immobilization technique is applicable to a specific process, and choices are usually made based on the costs and sensitivity required [200-224].

Adsorption is a simple but efficient method of enzymatic immobilization [225]. Adsorption can be of physical, ionic, or affinity nature, with physical adsorption being the most commonly used method [180]. The latter is probably the fastest, most straightforward, and economical technique [226]. It is a reversible method in which enzymes are physically bound to the support material. It involves weak intermolecular interactions, such as Van der Waals forces, electrostatic forces, hydrophobic interactions, and hydrogen bonds $[227,228]$. With this technique, immobilized enzymes can be easily removed from the support, allowing its reuse in subsequent immobilization cycles [229]. In the study carried out by Lin et al. [230], FeO@C nanoparticles functionalized with amine were used as magnetic carriers for laccase immobilization by adsorption. As a result, the operational, $\mathrm{pH}$, and storage stability of the immobilized laccase were significantly improved, and after 10 consecutive operations, it maintained its residual activity above $60 \%$. 


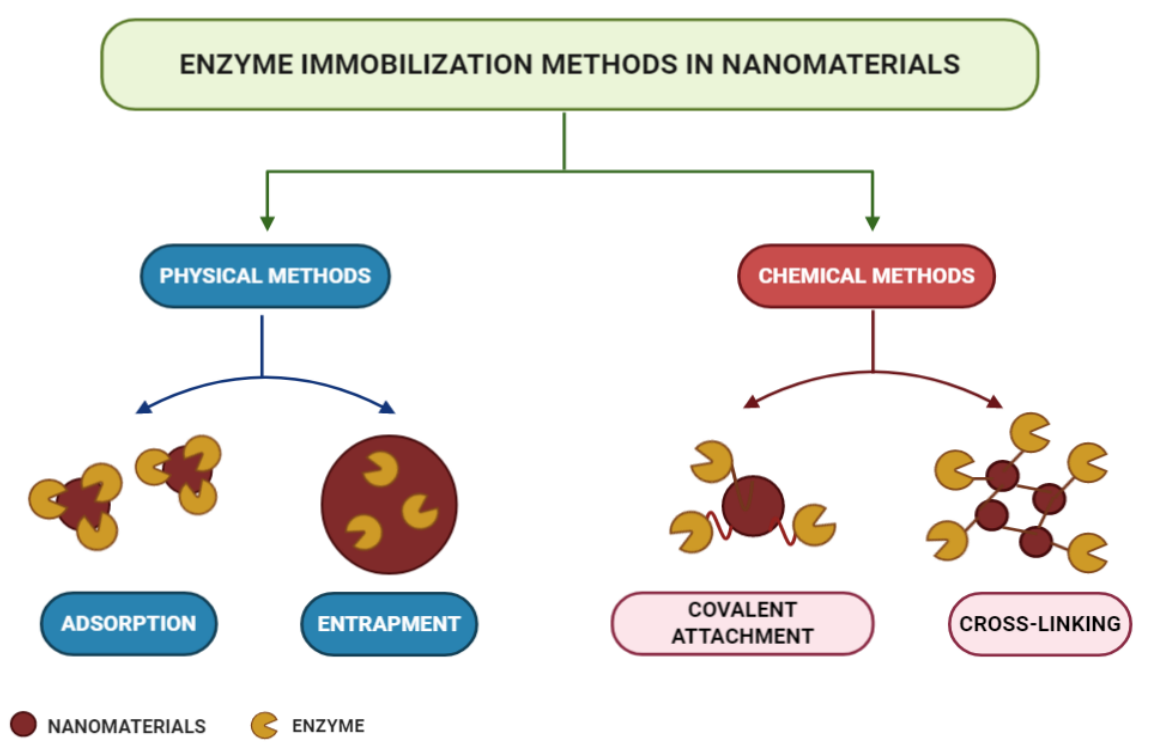

Figure 5. Enzyme immobilization methods.

The trapping method is based on the incorporation of the enzyme into a polymeric network by covalent or non-covalent bonds that enable the passage of the substrate while retaining the enzyme $[231,232]$. In this method, enzymes are not bound to the support matrix, unlike in other methods [233]. Different strategies can be used for entrapment, such as the inclusion of the enzymes within a highly cross-linked polymeric matrix, their dissolution in a non-aqueous phase, or their separation through semipermeable microcapsules [207]. The entrapment to charged polymeric membranes appears as an alternative to the functionalization method, since this allows the immobilization of enzymes at high concentrations [229-235]. The technique presents several advantages, as it does not require many steps or extensive purification stages, apart from being fast and the reaction being able to run under moderate conditions $[236,237]$. However, difficulties regarding diffusion exist in the transport of substrate and product, when these have high molecular weight [238]. In the study by $\mathrm{Xu}$ et al. [239], an Aspergillus niger lipase was doubly immobilized via encapsulation in $\mathrm{SiO}_{2}$ nanoparticles in sol-gel powder prepared with tetramethoxysilane (TMOS) and methyltreimetotoxysilane (MTMS) catalyzed polymerization. The results indicated that under ideal conditions, the immobilized lipase retained $92 \%$ of its protein load and $94 \%$ of its total enzymatic activity, in addition to showing higher thermal and $\mathrm{pH}$ stability than its free form, confirming their great potential for industrial applications.

Enzyme crosslinking involves a bifunctional agent, usually glutaraldehyde [240], in the preparation of immobilized enzymes without the need for a carrier [241]. The advantages of this approach are high enzyme activity and low production costs due to the exclusion of additional expensive carriers [211]. The cross-linked enzyme aggregate (CLEA) method is an independent immobilization technique, which enables the production of recyclable and stable biocatalysts with high activity retention $[242,243]$. They can be applied to immobilize almost all enzymes and present many positive economic advantages and environmental benefits in industrial biocatalysis $[237,244]$. They are produced by the crosslinking of enzymatic aggregates resulting from the mixing of an aqueous protein solution with organic solvents, polymers, or anionic salts, or by crosslinking the bifunctional reagent, which generates a three-dimensional polymeric matrix [228,245]. Doraiswamy, Sarathi, and Pennathur [246] carried out a study using nanoparticles of magnetite (MGNP-CLEAs) and graphene oxide (GO-CLEAs), cross-linked with glutaraldehyde, as supports for the immobilization of the enzyme Staphylococcus spp through the CLEA method. As a result, MGNP-CLEAs have been shown to have better stability over a wide temperature and $\mathrm{pH}$ range, together with an increase in their reusability and storage stability. 
Covalent bonding occurs through functional groups of enzymes that are not essential for its catalytic activity [247]. Nucleophilic functional groups of amino acid side chains, such as hydroxyl, amino, carboxylic, and thiol, are usually involved in the formation of these bonds [248]. Immobilization by covalent bonding is advantageous in that it forms strong bonds between the enzyme and the support, preventing enzyme leaching [249]. However, the amount of materials available commercially for covalent immobilization is low compared to immobilization by adsorption [250]. With the use of this technique, there is a slow release of enzymes and an improvement in its storage capacity and shelf life, so it is favorable for continuous applications at full scales [251]. Osuna et al. [252] studied the immobilization of Aspergillus niger lipases by covalent bonding on magnetic nanoparticles coated with chitosan (CMNP) and obtained by co-precipitation. The results showed high storage stability for 50 days in immobilized derivatives that maintained their initial activity above $80 \%$ after 15 hydrolytic cycles.

The characteristics of the support used for enzyme immobilization are fundamental factors to determine their performance $[190,253]$. An adequate support must present physical resistance to pressure and hydrophilicity, be readily available, and of low cost [254].

\section{Nanomaterial-Based Enzymes as Biosensors}

Enzyme-based biosensors are widely used, as well as immunosensors (which generally involve antibodies), genosensors (based on nucleic acids), and cell-based sensors, and these can be applied in the areas of food safety, health care, and environmental monitoring [14,255-258]. Enzyme immobilization onto transducers is crucial in the obtainment of enzyme-based biosensors, since it directly affects their lifespan and the time of enzymatic response $[14,52,259,260]$.

As mentioned previously, the underlying architecture of a biosensor consists of the appropriate combination of a biological portion (in this specific case, an enzyme) and a transducer [261,262]. Therefore, the most central aspect for designing such a device is the adequate combination between enzyme and electrode [238]. In addition, the sensitivity of the biosensor is directly proportional to the efficiency of the process of enzyme immobilization to the electrode $[14,47,238]$. Therefore, for this process to be successful and result in excellent biosensor efficiency, some factors must be taken into account, such as the class of enzyme, type of support, immobilization method, and final application [212,263]. These observations must be considered in early design stages because immobilization techniques can highly influence the properties of enzymes [212,263].

Concerning support materials, nanostructured materials are highlighted, as they have characteristics that justify and incentivize their application in the field of biosensors: high surface-to-volume ratio, good electrical conductivity, high reactivity, excellent magnetic properties, and the ability of synthesis of suitable enzyme-support derivatives [14,264]. In addition, the incorporation of nanomaterials in the design of biosensors can offer remarkable electronic, magnetic, and optical properties; they can also render enzyme immobilization processes more successful, facilitate electron transfers and make biocatalyzed reactions more specific $[265,266]$. Moreover, nanostructured materials are more biocompatible to a certain degree and allow enzymes to better maintain their catalytic activity $[14,238,267]$.

Among specific examples, gold nanoparticles $(10-30 \mathrm{~nm})$ have been shown as potential alternatives for biosensor applications due to the fact that their physicochemical properties (such as electrocatalytic, optical, thermal, and magnetic) depend on the size, shape, and biocompatibility of the biosensor [47]. The stability of the final composite material made from gold nanoparticles (AuNPs) became a promising platform for enzymatic biosensors [268]. Gold nanoparticles favor the transfer of electrons between a wide range of electroactive biological species and the electrode, which in turn enables the device to detect biocomposites at lower concentrations [47]. This principle is used mainly in the redox enzyme biosensor, where the bioreceptor unit catalyzes the oxidation or the reduction of the analyte [269]. The presence of functionalized AuNPs leads to a better bioelectrocatalytic response of the biosensor, besides promoting greater selectivity and 
sensitivity [270]. Moreover, easy modification of the gold surface by thiolated molecules makes AuNPs suitable across different biological arrangements.

Another noteworthy factor is that the transfer of electrons between enzyme and transducer can be improved by the use of nanomaterials [53,271,272]. This improvement is provided by the morphology and dimensions of these nanostructures, and the strong electrostatic interactions between the enzyme and the nanomaterials $[14,273]$. The immobilization of enzymes onto nanomaterials for the design of biosensors is extensively reported in the literature. Table 2 shows the types of materials that have been used in the production of enzymatic biosensors based on nanomaterials.

Table 2. Nanomaterial-based enzyme biosensors for different applications.

\begin{tabular}{|c|c|c|c|}
\hline Enzyme & Nanomaterial & Applications & Reference \\
\hline Glucose oxidase & Carbon nanotubes & Glucose biosensor & [137] \\
\hline Glucose oxidase & GR-MWNTs / AuNP ${ }^{(1)}$ & Glucose biosensor & [138] \\
\hline $\begin{array}{c}\text { Bovine serum amine } \\
\text { oxidase }\end{array}$ & 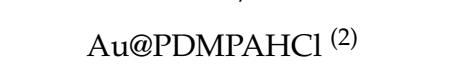 & $\begin{array}{c}\text { Biomedical } \\
\text { applications }\end{array}$ & [139] \\
\hline $\begin{array}{l}\text { Horseradish } \\
\text { peroxydase }\end{array}$ & Gold sononanoparticles & $\begin{array}{c}\text { Cyanide } \\
\text { determination }\end{array}$ & [274] \\
\hline DNA ligase & $\mathrm{Fe}_{3} \mathrm{O}_{4}$ & $\begin{array}{c}\text { Detection of genomic } \\
\text { DNA }\end{array}$ & [140] \\
\hline $\begin{array}{l}\text { Organophosphorus } \\
\text { Hydrolase }\end{array}$ & $\mathrm{Fe}_{3} \mathrm{O}_{4}$-silica NPs ${ }^{(3)}$ & $\begin{array}{l}\text { Direct detection of } \\
\text { paraoxon }\end{array}$ & [141] \\
\hline Plant esterase & CS/AuNPs-GNs ${ }^{(4)}$ & $\begin{array}{l}\text { Detection of } \\
\text { organophosphate } \\
\text { pesticides }\end{array}$ & [142] \\
\hline Diamine oxidase & Ceria nanospheres & $\begin{array}{c}\text { Determination of } \\
\text { putrescine in tiger } \\
\text { prawn }\end{array}$ & [143] \\
\hline Xanthine oxidase & $\begin{array}{l}\text { MNP-PAMAM-PtNP/rGO- } \\
\text { CMC }^{(5)}\end{array}$ & $\begin{array}{c}\text { Determination of } \\
\text { xanthine in fish meat }\end{array}$ & [144] \\
\hline $\begin{array}{c}\text { DNA } \\
\text { methyltransferase }\end{array}$ & Gold nanoparticles & $\begin{array}{l}\text { Detection of DNA } \\
\text { methyltransferase } \\
\text { activity }\end{array}$ & [275] \\
\hline $\begin{array}{c}\text { Human monoamine } \\
\text { oxidase B }\end{array}$ & $\mathrm{MnO}_{2}$ modified MWCNTs * & $\begin{array}{l}\text { Determination of } \\
\text { total monoamines }\end{array}$ & [145] \\
\hline Glucose oxidase & Tobacco mosaic virus & Glucose biosensor & [146] \\
\hline Glucose oxidase & Carbon ceramic & $\begin{array}{l}\text { Pore size effect in the } \\
\text { amount of } \\
\text { immobilized enzyme } \\
\text { for manufacturing } \\
\text { biosensors }\end{array}$ & [147] \\
\hline Tyrosinase & Carbon nanotubes & Phenol biosensor & [276] \\
\hline Xanthine oxidase & poly(l-aspartic acid)/MWCNT & $\begin{array}{l}\text { Detection of xanthine } \\
\text { in food industries }\end{array}$ & [148] \\
\hline Uricase & Chi-Gr cry/PB/SPCE ${ }^{(6)}$ & Uric acid detection & [149] \\
\hline
\end{tabular}

(1) Gold nanoparticles prepared with graphene and multi-walled carbon nanotubes; ${ }^{(2)}$ Core-shell gold nanoparticles stabilized with poly(3-dimethylammonium-1-propyne hydrochloride); ${ }^{(3)}$ Magnetic nanoparticles: silica coreshell; ${ }^{(4)}$ Chitosan/gold nanoparticles: graphene nanosheet; ${ }^{(5)}$ Poly(dopamine)-modified magnetic nanoparticles coated with four-generation ethylenediamine and core polyamidoamine G-4 dendrimers decorated with platinum nanoparticles on the surface of glassy carbon electrodes coated with graphene oxide and carboxymethylcellulose; (6) Porous cryogel platform of graphene-incorporated chitosan on top of a Prussian blue layer electrodeposited on a screen-printed carbon electrode. * Multi-walled carbon nanotubes (MWCNT).

By observing Table 2 above, it is evident the great interest of the scientific community in the development of new enzyme-based biosensors that incorporate nanomaterials for the most diverse demands. Their applications in the biomedical, environmental, food, and industrial sectors are discussed in the next sections. 


\subsection{Biomedical Applications}

The development of enzyme biosensors has improved and expedited the diagnosis of many diseases, such as diabetes, cancer, HIV, dengue, high cholesterol, and many other disorders that involve serum analysis $[127,277]$. To this end, the employment of enzyme biosensors present numerous positive aspects (simplicity, flexibility, cost-effectiveness, portability, and superior selectivity) $[278,279]$. Currently, only a few biosensors are commercially available, such as those for monitoring blood glucose. In the next sub-sections, we will discuss biosensor features used in the monitoring of diabetes, the role of cholesterol oxidase (COx) for determining cholesterol, the detection of biomarkers for cancer diagnostics, and the detection of lactate, which can be a strong indicator of health problems.

\subsubsection{Glucose Biosensors for Diabetes Monitoring}

Diabetic patients need to self-monitor blood glucose levels daily, which has proved challenging on many occasions [280,281]. Without strict control of their glucose levels, these patients can suffer health complications such as blindness, coronary artery diseases, stroke, and even kidney failure [282,283]. Due to the limitations and the importance of correct diagnostics, in recent years, considerable efforts have been made to create better techniques for determining blood glucose $[278,284]$. Enzymatic amperometric glucose biosensors are the devices most employed to this end, mainly because they are highly selective [285-287]. Among the enzymes used for detection, glucose oxidase (GOx) is a common choice owing to its relatively higher selectivity toward the monomer $[286,288]$. It is also easy to obtain, cheap, can withstand higher $\mathrm{pH}$ conditions, ionic strength, and temperature compared to other enzymes, such as hexokinase and glucose 1-dehydrogenase, for example $[127,289,290]$. Moreover, GOx catalyzes the oxidation of b-D-glucose into bD-glucono-1,5-lactone and hydrogen peroxide by using molecular oxygen as an electron acceptor [291,292]. Then, the quantification of glucose can be done either via the hydrogen peroxide produced or the oxygen consumed [285,293].

So far, three generations of glucose oxidase biosensors have been proposed. The first generation is based on the measurement of the hydrogen peroxide produced and the oxygen consumed [285]. This is because GOx usually oxidizes glucose into gluconolactone in the presence of oxygen and produces hydrogen peroxide $\left(\mathrm{H}_{2} \mathrm{O}_{2}\right)$ and water as by-products [294]. The main drawback of these first-generation biosensors is that the amperometric measurement of hydrogen peroxide requires a high operation potential to be able to act with high selectivity [286,291]. Another drawback is the limited solubility of oxygen in biological fluids, which produces oxygen tension changes that are known as "oxygen deficits" [127].

The second generation of glucose sensors, also known as "mediated glucose biosensors", have overcome the problem of their first-generation counterparts by the addition of a redox mediator (non-physiological electron acceptor), which transports electrons from the enzyme's active site to the electrode $[285,286]$. However, these mediators have high toxicity. Therefore, a third generation of glucose biosensors has emerged, basing on the direct electron transfer between GOx and the electrode without mediators $[7,287,295]$. Due to the slow deactivation, these biosensors require constant recalibration [285].

\subsubsection{Cholesterol Oxidase Applications in Biomedicine}

The rapid advance of cardiovascular diseases seen in the last decades is remarkably worrying. High blood cholesterol levels is an aggravating factor for these types of diseases, and it is of fundamental importance to detect them in their early stages, since when present in large quantities, cholesterol circulates in the blood and accumulates on the internal walls of arteries, making them narrower and less flexible [296]. Several enzymatic biosensors have been developed in recent years to accelerate the diagnosis of high cholesterol levels $[154,297,298]$. Most of them use the enzyme cholesterol oxidase (ChOx), which catalyzes the oxidation of cholesterol (cholest-5-en-3-ol) by employing oxygen as an 
electron acceptor, and it generates cholest-4-en-3-one and hydrogen peroxide $\left(\mathrm{H}_{2} \mathrm{O}_{2}\right)$ as by-products [299,300].

Similar to glucose biosensors, most of the cholesterol biosensors are based on the amperometric technique. In short, the biosensor controls the $\mathrm{O}_{2}$ consumption and the $\mathrm{H}_{2} \mathrm{O}_{2}$ production during the ChOx cholesterol catalysis [301,302]. Other cholesterol biosensors widely studied in recent years are those based on photometric indicators, such as luminescence, surface plasmon resonance, and fluorescence [295]. Recent studies report that ChOx from Bordetella spp. caused lung cancer cells both in vitro and in vivo to undergo irreversible apoptosis, besides promoting the generation of reactive oxygen species (ROS) [302-304]. These findings render ChOx a promising candidate for future anti-tumor therapies.

\subsubsection{Detection of Cancer Biomarkers}

MicroRNAs (miRNAs) are small, endogenous, and single-stranded noncoding RNAs that a play vital role in regulating gene expression through messenger RNAs [305,306]. They are involved in many physiological processes in the human body, and their abnormal regulation results in various diseases, including different types of cancer [307,308]. Graphene oxide and reduced graphene oxide both exhibit strong affinity for miRNAs via hydrogen bonding or $\pi-\pi$ interactions, and they are widely used for detecting this biomarker. In electrochemical miRNA detection, the transduction event measures the changes provoked by hybridization, employing electrochemically active reporter species, including enzyme-substrate pairs such as horseradish peroxidase or hydrogen peroxide, which delivers good sensitivity [309-311].

The enzyme-linked immunosorbent assay (ELISA) is a technique that is widely used for different applications, including cancer diagnostics [312]. Despite the simple operation and cost efficiency, it suffers from low sensitivity to biological samples [312]. Using nanomaterials as carriers of enzymes is an effective strategy, since they are able to increase the sensitivity of detecting markers of different types of cancer from 2 to 13 fold [313-316]. For this purpose, gold nanoparticles carrying the enzyme horseradish peroxidase are the most often used, but reports of employment of other nanomaterials and enzymes can also be found in the literature [312-314].

\subsubsection{Lactate Detection}

The concentration of lactate, or lactic acid, has been widely used as a key parameter in clinical diagnostics, both for assessing patient health conditions and for studying different diseases [317-319]. An accumulated concentration of this specific acid in the human body results in lactic acidosis, which causes several health problems, such as failures in the heart's left ventricular and in the renal and hepatic systems, sepsis, diabetes, and malignancy or inborn errors of metabolism [317,320].

Due to the simple enzymatic reactions and the facilitated production of biosensors, the most common enzymes used for lactate detection are L-lactate dehydrogenase (LDH) and L-lactate oxidase (LOD) [321]. The complexity and cost of conventional LOD biosensors render their use impractical [317]. The use of nanomaterials, and more specifically, of those that are carbon-based, can effectively solve the lower sensitivity and selectivity issues in LODs. Using these nanomaterials also increases the longevity of lactate biosensors [322-325].

Carbon nanodots have been receiving considerable attention in biosensing applications due to their water solubility, low cytotoxicity, high luminescence, and good conductivity $[326,327]$. To facilitate enzyme immobilization, they can be surrounded by different functional groups such as hydroxyl, carboxyl, and amide groups [328,329]. Bravo et al. used a simple and fast method to produce a lactate biosensor, which consisted of the direct adsorption of lactate oxidase onto carbon nanodots. Their biosensor had a sensitivity of $4.98 \times 10^{-3} \mu \mathrm{A} \cdot \mu \mathrm{M}^{-1}$ and a detection limit of $0.9 \mu \mathrm{M}$, similar to the commercial spectrophotometric enzymatic kit [322]. 
Diamond nanoparticles are carbon-based nanomaterials generated from carbon-containing explosives detonated under conditions of negative oxygen balance [330,331]. Their easy scaleup and moderate production cost, along with their biocompatibility and noncytotoxic nature, render them attractive for biosensing applications $[332,333]$. To this purpose, they require some structural modification, such as that done by Briones et al., who used (hydroxymethyl)ferrocene (HMF) as a redox mediator. Their developed lactate biosensor presented a linear concentration range from 0.02 to $1.2 \mathrm{mM}$, a sensitivity of $6.1 \mu \mathrm{AmM}^{-1}$, a detection limit of $5.3 \mu \mathrm{M}$, and very good stability [332].

\subsection{Environmental Applications}

In the last decades, the concerns involving environmental pollution have intensified due to the constant growth of contaminants and pollutants harmful to the environment [334]. There is a clear need for developing new methods for monitoring the levels of pollutants in the environment, such as heavy metals and pesticides [335,336]. Traditional analytical techniques, such as chromatographic methods, are challenging to incorporate because they require costly reagents, time-consuming sample pre-treatments, and expensive equipment, apart from not being efficient in in situ measurements, as in the case of accidental releases of pesticides or acute poisoning $[21,337,338]$. Thus, analytical methods for environmental monitoring are required to be practical, cost-effective, portable, and fast [338,339].

In this context, enzyme-based biosensors appear as a potential alternative, as they have several advantages over other traditional tools, by being economical, user-friendly, highly sensitive, accurate, and large-scale enabled [335,340,341]. Currently, the primary water and soil pollutants are heavy metals, such as aluminum (Al), cadmium (Cd), copper $(\mathrm{Cu})$, lead $(\mathrm{Pb})$, chromium $(\mathrm{Cr})$, mercury $(\mathrm{Hg})$, and zinc $(\mathrm{Zn})$ [342,343]; and pesticides, such as atrazine, endosulfan sulfate, diethyl atrazine, chlorpyrifos, etc. [344-346]. Therefore, two of the main applications of enzyme-based biosensors are in the analysis of water and soil samples for the detection of heavy metal or pesticide traces. Within this context, the next subsections will be dedicated to exploring the main concepts and studies concerning these applications.

\subsubsection{Heavy Metal Sensing}

Several enzymes, such as urease [347-349], horseradish peroxidase [343,350,351], glucose oxidase [287,352], invertase [353,354], and dehydrogenase [355-357] can be highly efficient in metal identification analyses, based either on the activation or on the inhibition of the specific enzyme. Heavy metals generally act as cofactors of metalloproteins to form an essential part of the structure that is required for enzyme activation $[335,342]$. Enzyme inhibition, on the other hand, occurs in the parts of the enzyme where the interaction between heavy metals and thiol or methylthiol groups of amino acids takes place [337,358]. Enzymatic methods are based on the inhibition behavior that several metal ions can cause in a wide range of enzymes (such as peroxidases, dehydrogenases, ureases), which are explicitly inhibited by low concentrations of a particular metal ion [353,359-362]. Nanoparticles can enhance electron transfer, increase conductivity, and offer high biocompatibility and catalytic efficiency, therefore composing inhibition biosensors with high sensitivity [350,362].

The deactivation of the enzyme urease was used in a system set up to monitor and detect heavy metals such as mercury, cadmium, and arsenic. Although the estimation was made based on enzymatic analyses, the application of immobilization techniques was not required. In addition, it was observed that the enzyme was completely deactivated in the presence of $20 \mathrm{ppb}$ mercury [342,361]. Urease was also employed in the design of enzymatic amperometric biosensors for the measurement of $\mathrm{Hg}^{+2}$, which is based on the inhibitory action of the ion on the urease activity [347,362]. To do that, the authors used screen-printed carbon electrodes as a support and electrodes modified with gold nanoparticles, resulting in a more sensitive analysis of this heavy metal [362]. 


\subsubsection{Organophosphoric Pesticide Sensing}

According to the EPA, pesticides are substances, or mixture of substances, intended for preventing, destroying, repelling, or diminishing damage caused by pests [360]. Pesticides are the major pollutants found in water, the atmosphere, soil, plants, and foods [363-365]. Biosensors are essential for detecting and monitoring these contaminants as they are simple, highly sensitive, and do not require extensive sample pre-treatment [338,366].

The main enzymes used for this purpose are cholinesterase (ChE), glucose oxidase (GOx), cholinesterase (AChE), urease, butyrylcholinesterase (BChE), and oraganophosphorushydrolase (OPH) $[359,367,368]$. In that regard, common techniques are enzymatic inhibition assays and immunoassays [369]. Inhibition-based biosensors have a disadvantage in the fact that the inhibition process takes place in several steps, with the incubation and reactivation, or regeneration, steps being time-consuming [369,370]. Acetylcholinesterase (AChE) inhibitors have been studied in the development of a paper-based biosensor. This biosensor could detect organophosphate and carbamate pesticides within very reasonable detection limits, with methomyl $=6.16 \times 10^{-4} \mathrm{mM}$ and profenophos $=0.27 \mathrm{mM}$ showing a fast response time of approximately $5 \mathrm{~min}$ [371].

Organophosphorus hydrolase (OPH) or phosphotriesterase is a bacterial enzyme that is capable of catalyzing the hydrolysis of many pesticides [372,373]. The enzymatic hydrolysis of pesticides includes $\mathrm{pH}$ changes and chromophoric species $[369,374]$. OPH has emerged as a promising alternative for detecting organophosphorus compounds, owing to its wide range of compatible substrates and its variety of possible bonds, such as P-F, $\mathrm{P}-\mathrm{O}, \mathrm{P}-\mathrm{S}$, and P-CN [375]. It is also highly specific for the detoxification of the PdF bond (G agents) of organophosphates such as sarin; however, OPH is ineffective for other classes of organophosphates such as PdO, PdS, and PdCN [335]. In another work, Du et al. designed a nanomaterial-based biosensor by covalently coupling OPH loaded on quantum dots with carbon nanotubes or gold composites. The detection limit was $1.0 \mathrm{ng} / \mathrm{mL}$ [376]. Furthermore, this biosensor showed high selectivity for detecting methyl parathion and many other interfering compounds, such as carbamate pesticides [376].

\subsection{Food Applications}

Detecting the presence and controlling the amount of toxic substances in foods is of paramount importance to this industry, not only because of the potentially harmful health effects on consumers but also to better manage the quality of the food produced, considering that the levels of toxins increase over time, which can be made worse due to poor conditions of processing and storage $[107,377]$. In this regard, enzymatic biosensors based on nanomaterials appear as good alternatives for monitoring the quality and safety of foods because they are highly sensitive, selective, fast, and also due to the possibility of miniaturization [377]. For example, nanomaterial-based enzyme biosensors are used in the food industry for the detection of harmful substances such as mycotoxins, pesticides, and other compounds, and their application in this sector for controlling these substances is widely reported [14,47,107,377-379].

In this scenario, one of the most pertinent issues is the contamination of food by pesticides, which is a constant issue in agricultural production [378]. Zhang et al. synthesized an acetylcholinesterase biosensor based on mesoporous carbon/ferroferric oxide-modified electrode for detecting organophosphorus pesticides. Chitosan was used as a dispersant to disperse ordered mesoporous carbons $(\mathrm{OMC})$, and $\mathrm{Fe}_{3} \mathrm{O}_{4}$ for fixing them firmly on the electrode surface, increasing its electrochemical response. With the use of this biosensor to detect pesticides in cabbage, rape, and lettuce samples, relative standard deviations between 0 and 4.51 and a recovery rate between $94 \%$ and $105 \%$ was observed. These results indicate that the proposed biosensor has remarkable accuracy, precision, and that the process is highly reproducible [275].

For a similar purpose, Zheng et al. synthesized a nanocomposite based on a glassy electrode functionalized with ionic liquid and gelatin. The nanocomposite obtained showed high conductivity and excellent biocompatibility with the enzyme acetylcholinesterase 
(AChE). A good rate of electron transfer was observed between the active site of the enzyme due to a good adhesion of AChE owing to the surface hydrophilicity of the electrode, which facilitated the access of substrates to active enzyme centers. The proposed biosensor was tested in the analysis of carbaryl and monocrotophos in spiked tomato juice samples. Their observations showed that the detection of carbaryl reached levels between $92.5 \%$ and $105.0 \%$, and for the detection of monocrotophos, this was between $91.2 \%$ and $110.0 \%$. The results confirmed that the proposed biosensor had good accuracy and sensitivity in analyses of food security [380].

More recently, Ma et al. discussed the synthesis and uses of a biosensor based on nanocomposites of $\mathrm{Pt}$ nanoparticles anchored to $\mathrm{UiO} 66-\mathrm{NH}_{2}$ as carriers to produce acetylcholinesterase biosensors for organophosphorus pesticide detection in samples of cabbage and apple. Their results showed that the synthesized biosensor presented high sensitivity, varying from $1 \times 10^{-14} \mathrm{M}$ to $1 \times 10^{-9} \mathrm{M}$, within a detection limit of $4.9 \times 10^{-15} \mathrm{M}$. Using the proposed biosensor, malathion recovery rates ranged from $93.34 \%$ to $97.80 \%$. These results demonstrate that the biosensor is a viable alternative for practical use [381].

Another issue in the food industry that could be solved by the detection and the control capabilities of biosensors is that of contamination by bacteria and other microorganisms. In this regard, Sánchez-Paniagua López et al. [377] studied and synthesized electrochemical enzyme biosensors based on calcium phosphate materials for tyramine detection in gouda and brie cheese samples using tyrosinase as the biological material. The resulting biosensor proved to be a reliable, highly sensitive, fast, cheap, and easy analytical method for detecting tyramine. Under optimal reaction conditions, a linear range of $5.8 \times 10^{-7}$ to $1.6 \times 10^{-5}$, sensitivity of $1.5 \times 10^{3} \mathrm{~mA} \mathrm{M}^{-1} \mathrm{~cm}^{-2}$, detection limit of $4.85 \times 10^{-8} \mathrm{M}$, and a response time of $6 \mathrm{~s}$ were obtained [377].

In another application, Sun et al. used the enzyme deoxy ribozyme to develop a colorimetric sensor based on a truncated aptamer and trivalent DNAzyme aimed at the determination of Vibrio parahemolyticus, which is a food-borne pathogen common in fresh salmon samples. In their work, the aptamer-conjugated magnetic nanoparticles (MNPs) were used as capture tools, and the G-quadruplex (G4) DNAzyme was used as the signal amplifier element. Under optimal reaction conditions, a considerable linear detection range of $10^{2}$ to $10^{7} \mathrm{CFU} / \mathrm{mL}$ was observed, in addition to a low detection limit of $10 \mathrm{CFU} / \mathrm{mL}$. Therefore, the synthesized biosensor showed good sensitivity and accuracy, making it a viable alternative for monitoring food quality without the need for more complicated operations [382].

Ethanol detection is used in clinical analyses and also to check the progress of fermentation processes in fermented beverage production [383-385]. Many different biosensing architectures are proposed in the literature, with the work of Revenga-Parra et al. being worthy of mention. The authors used diamond nanoparticles chemically modified with phenothiazine as carriers for the enzyme alcohol dehydrogenase [330]. The biosensor produced presented a persistent electrocatalytic effect toward the oxidation of NADH, good selectivity to ethanol, and very good analytical performance [330].

Thus being, several enzymatic biosensors based on nanomaterials have been reported for the most diverse purposes in the food industry, aiming at an improved detection of pesticides and microorganisms, as described above. It is clear that the technological potential of biosensors is being studied further to ensure better management, safety, and quality of foods, considering that the sector is directly linked to the well-being and quality of life of the wider population. Therefore, the need for more optimized sustainable practices and the rush to reduce negative environmental impacts by providing (bio-)technologies that can detect the concentration and toxicity of contaminants in foods, soil, and plantations has become an attractive research field that aims at ensuring the production and maintenance of safe and healthy food products. 


\subsection{Industrial Bioprocess Applications}

As described above, the basic architecture of a biosensor is given by the appropriate combination of a biological portion and a transducer, and the changes that are detected by the transducer are converted into tangible optical, electrical, or thermal signals, which are used to identify the analyte of interest [47]. Thus, depending on the type of electrode and the class of enzyme, these biosensors can applied in several industrial segments, such as in biomedical applications [19,47,137-139], in the monitoring of food, soil, and plantations [275,377,380,381], and in the detection of environmental pollutants [1]. The growing interest of these sectors in this type of device is explained by their high sensitivity and enzyme specificity toward the analytes of interest. In this sense, several categories of enzyme-based biosensors are capable of adapting to specific industrial applications based on the type of transducer used, for producing electrochemical, colorimetric/optical, or piezoelectric biosensors.

Electrochemical biosensors is the most used and reported class in the literature, having been applied in the biomedical field, in the food industry, for the detection of pollutants in the environment, etc. [47]. An example of an application in biomedicine, the work of Bäcker et al. reports the development of an electrochemical detector based on nanotubes of Tobacco mosaic virus (TMV) as a matrix for immobilizing glucose oxidase (GOD) using streptavidin (SA) as a bridge between TMV and GOD in Pt electrodes. The authors also investigated the immobilization strategy of streptavidin-conjugated GOD ((SA)-GOD) that would result in the most sensitive and accurate glucose detection: bio-affinity binding, adsorption, and crosslinking with glutardialdehyde. The results showed that glucose sensors with (SA)-GOD conjugates immobilized by adsorption and those equipped with (SA)-GOD crosslinked with glutardialdehyde presented a sensitivity of $1.4 \mathrm{nA} \mathrm{mM} \mathrm{mm}^{-1} \mathrm{~mm}^{-2}$ and $1.6 \mathrm{nA} \mathrm{mM} \mathrm{mm}^{-1} \mathrm{~mm}^{-2}$, respectively, in the linear range of $0.4-3.4 \mathrm{mM}$ glucose. On the other hand, biosensors based on bio-affinity (SA)-GOD resulted in a higher detection sensitivity of $4.9 \mathrm{nA} \mathrm{mM} \mathrm{mm}^{-1} \mathrm{~mm}^{-2}$ and $2.8 \mathrm{nA} \mathrm{mM}^{-1} \mathrm{~mm}^{-2}$, in the linear range of $0.1-7.4 \mathrm{mM}$ glucose [146].

Within the environmental area, electrochemical biosensors have also been successfully applied. In water treatment for the detection of contaminants, Maleki et al. proposed a new enzyme-based biosensor to detect catechol in water samples using artificial neural networks. In this study, poly (3,4-ethylenedioxy-thiophene) (PEDOT), graphene oxide nanosheets (GONs), and laccase (Lac) were used in the design of a biosensor to be placed on the glassy carbon electrode. The developed biosensor was successful for detecting catechol, and linear responses were obtained in two intervals, $0.036-0.35 \mu \mathrm{M}$ and $0.35-2.5 \mu \mathrm{M}$, with a detection limit of $0.032 \mu \mathrm{M}$. These results confirmed that the proposed model can be a powerful tool for catechol detection in water samples in real scenarios [386].

In addition, from the perspective food quality, another research line has focused on electrochemical enzyme-based biosensors. In this regard, Yazdanparast et al. developed an enzyme-based ultrasensitive electrochemical biosensor using poly(L-aspartic acid)/MWCNT bio-nanocomposite for xanthine detection in order to guarantee meat freshness. The biosensor was prepared using a multi-walled carbon nanotube (MWCNT) and a poly(L-aspartic acid) film for the immobilization of xanthine oxidase (XO) on a glassy carbon electrode (GCE). The developed model applied in the detection of xanthine in fish meat showed a linear range of $0.001-0.004 \mu \mathrm{M}$ and $0.005-50.0 \mu \mathrm{M}$, with a detection limit of $3.5 \times 10^{-4} \mu \mathrm{M}[148]$.

Another example of application in the food sector was carried out by Russian researchers, who patented a device to determine the content of glucose, lactate, ethanol, and starch in fermentation media or in products such as glucose syrup, resulting from food production streams. The purpose of the invention is to increase the accuracy of analyses of glucose, lactate, ethanol, and starch, and to extend the range of determination of the concentrations of such substances, deeming it a practical solution for this intended purpose. To this end, enzymatic preparations of glucose oxidase, alcohol oxidase, lactic oxidase, and a mixture of glucose oxidase and $\gamma$-amylase were covalently immobilized on graphite 
electrodes modified by single-walled carbon nanotubes. The data showed that the device met the proposed objective with good detection time and accuracy [387].

Concerning colorimetric biosensors, several studies have also reported optical detection to be an efficient tool to identify pathogens and toxins in the food industry. Wu et al. developed a simple colorimetric aptasensor system to detect Vibrio parahaemolyticus, which is a widespread food-borne pathogen. The method used magnetic (MNPs) and gold nanoparticles (AuNPs) as carriers of horseradish peroxidase (HRP) and aptamers, which served as signal probes. In the presence of the analyte, optical signals were generated, and under optimal conditions, these were linearly dependent on the Vibrio parahaemolyticus concentrations from 10 to $10^{6} \mathrm{cfu} / \mathrm{mL}$ in a logarithmic graph, with a detection limit of $10 \mathrm{cfu} / \mathrm{mL}$. Due to the presence of the gold nanoparticles, a large amount of horseradish peroxidase could be loaded, which resulted in an amplification of the signal and an improvement in the sensitivity of the biosensor [388].

Based on the principle of photosensitive detection, Lu et al. [389] patented a biosensor using a photonic crystal sensor with immobilized urease for the determination of heavy metal ions in industrial effluents under the justification that such effluents could be harmful to both humans and the environment. According to their experimental data, because the system was designed using an immobilized enzyme, the biosensor allowed for repeated analyses and thus reduced the costs of detection. Additionally, due to the physical characteristics of the support, the mass transfer resistance between the analyte and the biosensor was reduced and the analysis was facilitated. Therefore, when comparing other strategies for detecting heavy metals in samples, this particular invention proved to be simpler to operate, to have greater sensitivity and stability, and result in shorter response times [389].

Another invention related to photodetection was reported by Honghui et al., who worked with MWCNT doped with iron nanoparticles used as a tint for the immobilizing of peroxidase (EC 1.1.11.7). According to the inventors, the biosensor proposed can be used in the detection of hydrogen peroxide and glucose, considering that these substances are by-products from several industrial bioprocesses. In this sense, apart from the good analyte detection levels, the invention enabled the reuse of the biosensor and its incorporation by the industry [390].

As discussed, several enzymatic biosensors based on nanomaterials have been employed across different industries for the most diverse purposes, such as for biomedical applications, in food safety and quality, and for pollutant detection. Therefore, the technological potential of biosensors is in increasing development to ensure better management, safety, and quality of foods, human health, and the environment.

\section{Conclusions and Future Trends}

As discussed in this review, nanomaterials of different types and properties are currently being researched and developed for use across many areas of interest. The incorporation of nanotechnology to the already consolidated enzyme-based biosensing techniques has been granting even more relevance and applicability to biosensors [8,47]. Among their advantages, it can be noted that nanomaterials are usually cost-effective; they can enhance the electrochemical signal conversion of transducers, reduce response times, and they are more stable and biocompatible than their non-nano counterparts $[8,14,65]$. However, there are still a few issues regarding their use that require further research before they can see a more widespread implementation.

For example, Batool et al. [65] discussed that the usual method for creating nanolayers on the transducer surface leads to random surface thickness and affects the performance of electrochemical biosensors [65]. In this sense, it is necessary to study alternative immobilization methodologies aimed at nanolayer formation in order to produce biosensors with uniform and controllable characteristics [65].

It is also worth mentioning that it is quite challenging to produce graphene with a well-defined size and precise surface chemistry. Moreover, to this end, it is necessary to focus on its biocompatibility, versatility, and reusability [391]. Another trend is to produce 
biosensors by combining two or more novel nanomaterials, which is currently attracting considerable attention [8]. These hybrid nanomaterials often show synergetic effects among their constituents, enabling the development of highly sensitive biosensors for wearable applications [8].

Despite their significant potential, nanomaterials-based biosensors are still in the early stages of use regarding the detection of pesticides, pharmaceutical compounds, and other hazards in real applications [14]. More research is needed for achieving highly optimized ways of developing new nanomaterials that improve the sensitivity, selectivity, stability, and catalytic activity of the systems involved [14]. As a consequence, with these novel materials being developed, other novel and appropriate immobilization protocols will also need to be designed $[14,64]$. All these considerations need to be at the center of the focus of the research being done into the next generation of nanometric enzyme-based biosensors.

Author Contributions: Conceptualization, F.T.T.C. and M.C.M.d.S.; Formal analysis, F.T.T.C., A.L.B.d.O., M.C.M.d.S. and J.C.S.d.S.; Methodology, M.C.M.d.S. and J.C.S.d.S.; Project administration, J.C.S.d.S.; Resources, F.T.T.C. and M.C.M.d.S.; Supervision, M.C.M.d.S. and J.C.S.d.S.; Writing—original draft, F.T.T.C., A.L.B.d.O., I.R.d.A.F., J.E.d.S.S., T.G.R., I.G.d.S. and A.L.G.C.; Writing-review and editing, M.C.M.d.S. and J.C.S.d.S. All authors have read and agreed to the published version of the manuscript.

Funding: This research was funded by Fundação Cearense de Apoio ao Desenvolvimento Científico e Tecnológico (FUNCAP), grant numbers BP3-0139-00005.01.00/18 and PNE-0112-00048.01.00/16; Conselho Nacional de Desenvolvimento Científico e Tecnológico (CNPq), grant numbers 422942/2016-2, 409058/2015-5, 408790/2016-4 and 311062/2019-9; Coordenação de Aperfeiçoamento de Ensino Superior (CAPES-Finance Code 001).

Institutional Review Board Statement: Not applicable.

Informed Consent Statement: Not applicable.

Acknowledgments: We gratefully acknowledge the financial support of the Brazilian Agencies for Scientific and Technological Development: Fundação Cearense de Apoio ao Desenvolvimento Científico e Tecnológico (FUNCAP BP3-0139-00005.01.00/18); Conselho Nacional de Desenvolvimento Científico e Tecnológico (CNPq, 408790/2016-4, 422942/2016-2 and 311062/2019-9); Coordenação de Aperfeiçoamento de Ensino Superior (CAPES).

Conflicts of Interest: The authors declare no conflict of interest.

\section{References}

1. Mehrotra, P. Biosensors and their applications-A review. J. Oral Biol. Craniof. Res. 2016, 6, 153-159. [CrossRef] [PubMed]

2. Andryukov, B.G.; Besednova, N.N.; Romashko, R.V.; Zaporozhets, T.S.; Efimov, T.A. Label-free biosensors for laboratory-based diagnostics of infections: Current achievements and new trends. Biosensors 2020, 10, 690041. [CrossRef]

3. Honeychurch, K.C.; Piano, M. Electrochemical (bio) sensors for environmental and food analyses. Biosensors 2018, 8, 57. [CrossRef]

4. Morales, M.A.; Halpern, J.M. Guide to Selecting a Biorecognition Element for Biosensors. Bioconjug. Chem. 2018, 29, 3231-3239. [CrossRef] [PubMed]

5. Homola, J. Surface plasmon resonance sensors for detection of chemical and biological species. Chem. Rev. 2008, 108, 462-493. [CrossRef] [PubMed]

6. Das, P.; Das, M.; Chinnadayyala, S.R.; Singha, I.M.; Goswami, P. Recent advances on developing 3rd generation enzyme electrode for biosensor applications. Biosens. Bioelectron. 2016, 79, 386-397. [CrossRef] [PubMed]

7. Wang, J. Electrochemical glucose biosensors. Chem. Rev. 2008, 108, 814-825. [CrossRef]

8. Yoon, J.; Shin, M.; Lee, T.; Choi, J.W. Highly sensitive biosensors based on biomolecules and functional nanomaterials depending on the types of nanomaterials: A perspective review. Materials 2020, 13, 1-21. [CrossRef]

9. Wang, J. Nanomaterial-based electrochemical biosensors. Analyst 2005, 130, 421-426. [CrossRef] [PubMed]

10. Yang, W.; Ratinac, K.R.; Ringer, S.R.; Thordarson, P.; Gooding, J.J.; Braet, F. Carbon nanomaterials in biosensors: Should you use nanotubes or graphene. Angew. Chem. Int. Ed. 2010, 49, 2114-2138. [CrossRef]

11. Song, Y.; Luo, Y.; Zhu, C.; Li, H.; Du, D.; Lin, Y. Recent advances in electrochemical biosensors based on graphene two-dimensional nanomaterials. Biosens. Bioelectron. 2016, 76, 195-212. [CrossRef] [PubMed]

12. Li, Y.C.E.; Lee, I.C. The Current Trends of Biosensors in Tissue Engineering. Biosensors 2020, 10, 88. [CrossRef] [PubMed]

13. Thévenot, D.R.; Toth, K.; Durst, R.A.; Wilson, G.S. Electrochemical biosensors: Recommended definitions and classification. Biosens. Bioelectron. 2001, 16, 121-131. [CrossRef] 
14. Kurbanoglu, S.; Ozkan, S.A.; Merkoçi, A. Nanomaterials-based enzyme electrochemical biosensors operating through inhibition for biosensing applications. Biosens. Bioelectron. 2017, 89, 886-898. [CrossRef]

15. Lazcka, O.; Del Campo, F.J.; Muñoz, F.X. Pathogen detection: A perspective of traditional methods and biosensors. Biosens. Bioelectron. 2007, 22, 1205-1217. [CrossRef]

16. Nguyen, H.H.; Kim, M. An Overview of Techniques in Enzyme Immobilization. Appl. Sci. Converg. Technol. 2017, 26, 157-163. [CrossRef]

17. Beheshti-Marnani, A.; Hatefi-Mehrjardi, A.; Es'haghi, Z. A sensitive biosensing method for detecting of ultra-trace amounts of AFB1 based on "Aptamer/reduced graphene oxide" nano-bio interaction. Colloids Surf. B Biointerfaces 2019, 175, 98-105. [CrossRef]

18. Amine, A.; Arduini, F.; Moscone, D.; Palleschi, G. Recent advances in biosensors based on enzyme inhibition. Biosens. Bioelectron. 2016, 76, 180-194. [CrossRef]

19. Rocchitta, G.; Spanu, A.; Babudieri, S.; Latte, G.; Madeddu, G.; Galleri, G.; Nuvoli, S.; Bagella, P.; Demartis, M.; Fiore, V.; et al. Enzyme Biosensors for Biomedical Applications: Strategies for Safeguarding Analytical Performances in Biological Fluids. Sensors 2016, 16, 780. [CrossRef]

20. Hassani, S.; Momtaz, S.; Vakhshiteh, F.; Maghsoudi, A.S.; Ganjali, M.R.; Norouzi, P.; Abdollahi, M. Biosensors and their applications in detection of organophosphorus pesticides in the environment. Arch. Toxicol. 2017, 91, 109-130. [CrossRef] [PubMed]

21. Georgakilas, V.; Tiwari, J.N.; Kemp, K.C.; Perman, J.A.; Bourlinos, A.B.; Kim, K.S.; Zboril, R. Noncovalent Functionalization of Graphene and Graphene Oxide for Energy Materials, Biosensing, Catalytic, and Biomedical Applications. Chem. Rev. 2016, 116, 5464-5519. [CrossRef]

22. Xiong, S.; Deng, Y.; Zhou, Y.; Gong, D.; Xu, Y.; Yang, L.; Chen, H.; Chen, L.; Song, T.; Luo, A.; et al. Current progress in biosensors for organophosphorus pesticides based on enzyme functionalized nanostructures: A review. Anal. Methods 2018, 10, 5468-5479. [CrossRef]

23. Masson, J.F. Surface Plasmon Resonance Clinical Biosensors for Medical Diagnostics. ACS Sens. 2017, 2, 16-30. [CrossRef]

24. Saylan, Y.; Erdem, Ö.; Ünal, S.; Denizli, A. An alternative medical diagnosis method: Biosensors for virus detection. Biosensors 2019, 9, 65. [CrossRef]

25. Yousefi, H.; Mahmud, A.; Chang, D.; Das, J.; Gomis, S.; Chen, J.B.; Wang, H.; Been, T.; Yip, L.; Coomes, E.; et al. Detection of SARS-CoV-2 Viral Particles Using Direct, Reagent-Free Electrochemical Sensing. J. Am. Chem. Soc. 2021, 143, 1722-1727. [CrossRef]

26. Perumal, V.; Hashim, U. Advances in biosensors: Principle, architecture and applications. J. Appl. Biomed. 2014, 12, 1-15. [CrossRef]

27. Antiochia, R. Developments in biosensors for CoV detection and future trends. Biosens. Bioelectron. 2020, 112777. [CrossRef] [PubMed]

28. Zhang, Q.; Wu, Y.; Xu, Q.; Ma, F.; Zhang, C. yang Recent advances in biosensors for in vitro detection and in vivo imaging of DNA methylation. Biosens. Bioelectron. 2021, 171, 112712. [CrossRef]

29. Ding, C.; Tian, Y. Gold nanocluster-based fluorescence biosensor for targeted imaging in cancer cells and ratiometric determination of intracellular pH. Biosens. Bioelectron. 2015, 65, 183-190. [CrossRef] [PubMed]

30. Suvarnaphaet, P.; Pechprasarn, S. Graphene-Based Materials for Biosensors: A Review. Sensors 2017, 17, 2161. [CrossRef] [PubMed]

31. Peña-Bahamonde, J.; Nguyen, H.N.; Fanourakis, S.K.; Rodrigues, D.F. Recent advances in graphene-based biosensor technology with applications in life sciences. J. Nanobiotechnol. 2018, 16. [CrossRef]

32. Batır, G.G.; Arık, M.; Caldıran, Z.; Turut, A.; Aydogan, S. Synthesis and Characterization of Reduced Graphene Oxide/Rhodamine 101 (rGO-Rh101) Nanocomposites and Their Heterojunction Performance in rGO-Rh101/p-Si Device Configuration. J. Electron. Mater. 2018, 47, 329-336. [CrossRef]

33. Wu, X.; Xing, Y.; Zeng, K.; Huber, K.; Zhao, J.X. Study of Fluorescence Quenching Ability of Graphene Oxide with a Layer of Rigid and Tunable Silica Spacer. Langmuir 2018, 34, 603-611. [CrossRef] [PubMed]

34. Wang, F.; Horikawa, S.; Hu, J.; Wikle, H.C.; Chen, I.H.; Du, S.; Liu, Y.; Chin, B.A. Detection of Salmonella typhimurium on spinach using phage-based magnetoelastic biosensors. Sensors 2017, 17, 386. [CrossRef]

35. Cheng, S.; Hideshima, S.; Kuroiwa, S.; Nakanishi, T.; Osaka, T. Label-free detection of tumor markers using field effect transistor (FET)-based biosensors for lung cancer diagnosis. Sens. Actuators B Chem. 2015, 212, 329-334. [CrossRef]

36. Logan, B.E.; Rossi, R.; Ragab, A.; Saikaly, P.E. Electroactive microorganisms in bioelectrochemical systems. Nat. Rev. Microbiol. 2019, 17, 307-319. [CrossRef] [PubMed]

37. Chu, N.; Liang, Q.; Jiang, Y.; Zeng, R.J. Microbial electrochemical platform for the production of renewable fuels and chemicals. Biosens. Bioelectron. 2020, 150, 111922. [CrossRef] [PubMed]

38. Prévoteau, A.; Rabaey, K. Electroactive Biofilms for Sensing: Reflections and Perspectives. ACS Sens. 2017, 2, 1072-1085. [CrossRef]

39. ElMekawy, A.; Hegab, H.M.; Pant, D.; Saint, C.P. Bio-analytical applications of microbial fuel cell-based biosensors for onsite water quality monitoring. J. Appl. Microbiol. 2018, 124, 302-313. [CrossRef] 
40. Abdalhai, M.H.; Fernandes, A.M.; Xia, X.; Musa, A.; Ji, J.; Sun, X. Electrochemical Genosensor to Detect Pathogenic Bacteria (Escherichia coli O157:H7) As Applied in Real Food Samples (Fresh Beef) to Improve Food Safety and Quality Control. J. Agric. Food Chem. 2015, 63, 5017-5025. [CrossRef] [PubMed]

41. Zhang, X.; Jiang, Y.; Zhu, M.; Xu, Y.; Guo, Z.; Shi, J.; Han, E.; Zou, X.; Wang, D. Electrochemical DNA sensor for inorganic mercury(II) ion at attomolar level in dairy product using $\mathrm{Cu}(\mathrm{II})$-anchored metal-organic framework as mimetic catalyst. Chem. Eng. J. 2020, 383, 123182. [CrossRef]

42. Malvano, F.; Pilloton, R.; Albanese, D. Sensitive detection of Escherichia coli O157:H7 in food products by impedimetric immunosensors. Sensors 2018, 18, 2168. [CrossRef]

43. Han, E.; Li, X.; Zhang, Y.; Zhang, M.; Cai, J.; Zhang, X. Electrochemical immunosensor based on self-assembled gold nanorods for label-free and sensitive determination of Staphylococcus aureus. Anal. Biochem. 2020, 113982. [CrossRef]

44. Jung, Y.; Kang, H.J.; Lee, J.M.; Jung, S.O.; Yun, W.S.; Chung, S.J.; Chung, B.H. Controlled antibody immobilization onto immunoanalytical platforms by synthetic peptide. Anal. Biochem. 2008, 374, 99-105. [CrossRef]

45. Kirsch, J.; Siltanen, C.; Zhou, Q.; Revzin, A.; Simonian, A. Biosensor technology: Recent advances in threat agent detection and medicine. Chem. Soc. Rev. 2013, 42, 8733-8768. [CrossRef]

46. Borisov, S.M.; Wolfbeis, O.S. Optical biosensors. Chem. Rev. 2008, 108, 423-461. [CrossRef] [PubMed]

47. Nguyen, H.H.; Lee, S.H.; Lee, U.J.; Fermin, C.D.; Kim, M. Immobilized enzymes in biosensor applications. Materials 2019, $12,121$. [CrossRef] [PubMed]

48. Rocha, T.G.; Pedro, P.H.; de Souza, M.C.M.; Monteiro, R.R.C.; dos Santos, J.C.S. Lipase Cocktail for Optimized Biodiesel Production of Free Fatty Acids from Residual Chicken Oil. Catal. Lett. 2020. [CrossRef]

49. Ronkainen, N.J.; Halsall, H.B.; Heineman, W.R. Electrochemical biosensors. Chem. Soc. Rev. 2010, 39, 1747-1763. [CrossRef] [PubMed]

50. Monteiro, R.R.C.; Lima, P.J.M.; Pinheiro, B.B.; Freire, T.M.; Dutra, L.M.U.; Fechine, P.B.A.; Gonçalves, L.R.B.; de Souza, M.C.M.; dos Santos, J.C.S.; Fernandez-Lafuente, R. Immobilization of Lipase A from Candida antarctica onto Chitosan-Coated Magnetic Nanoparticles. Int. J. Mol. Sci. 2019, 20, 4018. [CrossRef]

51. Secchi, O.; Zinellu, M.; Spissu, Y.; Pirisinu, M.; Bazzu, G.; Migheli, R.; Desole, M.S.; O’Neill, R.D.; Serra, P.A.; Rocchitta, G. Further in-vitro characterization of an implantable biosensor for ethanol monitoring in the brain. Sensors 2013, 13, 9522-9535. [CrossRef] [PubMed]

52. Songa, E.A.; Okonkwo, J.O. Recent approaches to improving selectivity and sensitivity of enzyme-based biosensors for organophosphorus pesticides: A review. Talanta 2016, 155, 289-304. [CrossRef] [PubMed]

53. Zhu, C.; Yang, G.; Li, H.; Du, D.; Lin, Y. Electrochemical sensors and biosensors based on nanomaterials and nanostructures. Anal. Chem. 2015, 87, 230-249. [CrossRef]

54. Zhang, Y.; Wu, M.; Wu, M.; Zhu, J.; Zhang, X. Multifunctional Carbon-Based Nanomaterials: Applications in Biomolecular Imaging and Therapy. ACS Omega 2018, 3, 9126-9145. [CrossRef]

55. Feng, H.; Tang, L.; Zeng, G.; Zhou, Y.; Deng, Y.; Ren, X.; Song, B.; Liang, C.; Wei, M.; Yu, J. Core-shell nanomaterials: Applications in energy storage and conversion. Adv. Colloid Interface Sci. 2019, 267, 26-46. [CrossRef] [PubMed]

56. Mitter, N.; Hussey, K. Moving policy and regulation forward for nanotechnology applications in agriculture. Nat. Nanotechnol. 2019, 14, 508-510. [CrossRef]

57. Falco, A.; Mallavia, R. Electrospun Nanomaterials: Applications in Food, Environmental Remediation, and Bioengineering. Nanomaterials 2020, 10, 1714. [CrossRef]

58. Wang, J.; He, Z.-W.; Jiang, J.-X. Nanomaterials: Applications in the diagnosis and treatment of pancreatic cancer. World J. Gastrointest. Pharm. Ther. 2020, 11, 1-7. [CrossRef]

59. Kim, S.E.; Tiwari, A.P. Three dimensional polycaprolactone/cellulose scaffold containing calcium-based particles: A new platform for bone regeneration. Carbohydr. Polym. 2020, 250, 116880. [CrossRef] [PubMed]

60. Tiwari, A.P.; Chhetri, K.; Kim, H.; Ji, S.; Chae, S.-H.; Kim, T.; Kim, H.Y. Self-assembled polypyrrole hierarchical porous networks as the cathode and porous three dimensional carbonaceous networks as the anode materials for asymmetric supercapacitor. $J$. Energy Storage 2021, 33, 102080. [CrossRef]

61. Ji, S.M.; Tiwari, A.P.; Kim, H.Y. Graphene Oxide Coated Zinc Oxide Core-Shell Nanofibers for Enhanced Photocatalytic Performance and Durability. Coatings 2020, 10, 1183. [CrossRef]

62. Blondeau, D.; Roy, L.; Dumont, S.; Godin, G.; Martineau, I. Physicians' and pharmacists' attitudes toward the use of sedation at the end of life: Influence of prognosis and type of suffering. J. Palliat. Care 2005, 21, 238-245. [CrossRef]

63. Nel, A.; Xia, T.; Mädler, L.; Li, N. Toxic potential of materials at the nanolevel. Science 2006, 311, 622-627. [CrossRef]

64. Adeel, M.; Bilal, M.; Rasheed, T.; Sharma, A.; Iqbal, H.M.N.; Iqbal, M.N. Graphene and graphene oxide: Functionalization and nano-bio-catalytic system for enzyme immobilization and biotechnological perspective. Int. J. Biol. Macromol. 2018, 120, 1430-1440. [CrossRef] [PubMed]

65. Batool, R.; Rhouati, A.; Nawaz, M.H.; Hayat, A.; Marty, J.L. A review of the construction of nano-hybrids for electrochemical biosensing of glucose. Biosensors 2019, 9, 46. [CrossRef]

66. Baughman, R.H.; Zakhidov, A.A.; De Heer, W.A. Carbon nanotubes-The route toward applications. Science 2002, $297,787-792$. [CrossRef] [PubMed]

67. Silvestre, J.; Silvestre, N.; De Brito, J. Review on concrete nanotechnology. Eur. J. Environ. Civ. Eng. 2016, 20, 455-485. [CrossRef] 
68. Krishna, V.D.; Wu, K.; Su, D.; Cheeran, M.C.J.; Wang, J.P.; Perez, A. Nanotechnology: Review of concepts and potential application of sensing platforms in food safety. Food Microbiol. 2018, 75, 47-54. [CrossRef]

69. Contreras, J.E.; Rodríguez, E.A. Nanostructured insulators-A review of nanotechnology concepts for outdoor ceramic insulators. Ceram. Int. 2017, 43, 8545-8550. [CrossRef]

70. Kolahalam, L.A.; Kasi Viswanath, I.V.; Diwakar, B.S.; Govindh, B.; Reddy, V.; Murthy, Y.L.N. Review on nanomaterials: Synthesis and applications. Mater. Today Proc. 2019, 18, 2182-2190. [CrossRef]

71. Aricò, A.S.; Bruce, P.; Scrosati, B.; Tarascon, J.M.; Van Schalkwijk, W. Nanostructured materials for advanced energy conversion and storage devices. Nat. Mater. 2005, 4, 366-377. [CrossRef] [PubMed]

72. Jeevanandam, J.; Barhoum, A.; Chan, Y.S.; Dufresne, A.; Danquah, M.K. Review on nanoparticles and nanostructured materials: History, sources, toxicity and regulations. Beilstein J. Nanotechnol. 2018, 9, 1050-1074. [CrossRef] [PubMed]

73. Lu, C.; Chen, X. Carbon nanotubes/graphitic carbon nitride nanocomposites for all-solid-state supercapacitors. Sci. China Technol. Sci. 2020, 63, 1714-1720. [CrossRef]

74. Dong, Y.; Wang, Y.K.; Yuan, F.; Johnston, A.; Liu, Y.; Ma, D.; Choi, M.J.; Chen, B.; Chekini, M.; Baek, S.W.; et al. Bipolar-shell resurfacing for blue LEDs based on strongly confined perovskite quantum dots. Nat. Nanotechnol. 2020, 15, 668-674. [CrossRef]

75. Fenzl, C.; Hirsch, T.; Baeumner, A.J. Nanomaterials as versatile tools for signal amplification in (bio)analytical applications. TrAC Trends Anal. Chem. 2016, 79, 306-316. [CrossRef]

76. Cao, X.; Tan, C.; Zhang, X.; Zhao, W.; Zhang, H. Solution-Processed Two-Dimensional Metal Dichalcogenide-Based Nanomaterials for Energy Storage and Conversion. Adv. Mater. 2016, 28, 6167-6196. [CrossRef]

77. Gholami, A.; Pourfayaz, F.; Maleki, A. Recent Advances of Biodiesel Production Using Ionic Liquids Supported on Nanoporous Materials as Catalysts: A Review. Front. Energy Res. 2020, 8. [CrossRef]

78. Mamba, G.; Gangashe, G.; Moss, L.; Hariganesh, S.; Thakur, S.; Vadivel, S.; Mishra, A.K.; Vilakati, G.D.; Muthuraj, V.; Nkambule, T.T.I. State of the art on the photocatalytic applications of graphene based nanostructures: From elimination of hazardous pollutants to disinfection and fuel generation. J. Environ. Chem. Eng. 2020, 8, 103505. [CrossRef]

79. Kujur, S.; Pathak, D.D. Reduced graphene oxide-immobilized iron nanoparticles Fe(0)@rGO as heterogeneous catalyst for one-pot synthesis of series of propargylamines. Res. Chem. Intermed. 2020, 46, 369-384. [CrossRef]

80. Shah, K.W.; Li, W. A review on catalytic nanomaterials for volatile organic compounds VOC removal and their applications for healthy buildings. Nanomaterials 2019, 9, 910. [CrossRef] [PubMed]

81. Liu, Y.; Zhou, G.; Liu, K.; Cui, Y. Design of Complex Nanomaterials for Energy Storage: Past Success and Future Opportunity. Acc. Chem. Res. 2017, 50, 2895-2905. [CrossRef]

82. Lee, Y.V.; Tian, B. Learning from Solar Energy Conversion: Biointerfaces for Artificial Photosynthesis and Biological Modulation. Nano Lett. 2019, 19, 2189-2197. [CrossRef]

83. Wang, H.; Liang, X.; Wang, J.; Jiao, S.; Xue, D. Multifunctional inorganic nanomaterials for energy applications. Nanoscale 2020, 12, 14-42. [CrossRef] [PubMed]

84. Sun, X.; Guo, Y.; Wu, C.; Xie, Y. The Hydric Effect in Inorganic Nanomaterials for Nanoelectronics and Energy Applications. Adv. Mater. 2015, 27, 3850-3867. [CrossRef]

85. Hu, M.; Yao, Z.; Wang, X. Graphene-Based Nanomaterials for Catalysis. Ind. Eng. Chem. Res. 2017, 56, 3477-3502. [CrossRef]

86. Wei, Y.; Yan, L.; Ma, C.; Zhang, C.; Sun, S.; Wen, X.; Yang, Y.; Li, Y. Mesoporous Iron Oxide Nanoparticle-Decorated Graphene Oxide Catalysts for Fischer-Tropsch Synthesis. ACS Appl. Nano Mater. 2020, 3, 7182-7191. [CrossRef]

87. Ogata, H.; Yoshimoto, S. Tuning of 2D Nanographene Adlayers on Au(111) by Electrodeposition of Metal Halide Complexes. ACS Appl. Mater. Interfaces 2019, 11, 46361-46367. [CrossRef] [PubMed]

88. Menazea, A.A.; Ahmed, M.K. Synthesis and antibacterial activity of graphene oxide decorated by silver and copper oxide nanoparticles. J. Mol. Struct. 2020, 1218, 128536. [CrossRef]

89. Jagiello, K.; Chomicz, B.; Avramopoulos, A.; Gajewicz, A.; Mikolajczyk, A.; Bonifassi, P.; Papadopoulos, M.G.; Leszczynski, J.; Puzyn, T. Size-dependent electronic properties of nanomaterials: How this novel class of nanodescriptors supposed to be calculated? Struct. Chem. 2017, 28, 635-643. [CrossRef]

90. Halappanavar, S.; Saber, A.T.; Decan, N.; Jensen, K.A.; Wu, D.; Jacobsen, N.R.; Guo, C.; Rogowski, J.; Ismo, K.K.; Levin, M.; et al. Transcriptional Profiling Identifies Physicochemical Properties of Nanomaterials That Are Determinants of the In Vivo Pulmonary Response. Environ. Mol. Mutagen. 2015, 56, 245-264. [CrossRef]

91. Chen, Y.; Fan, Z.; Zhang, Z.; Niu, W.; Li, C.; Yang, N.; Chen, B.; Zhang, H. Two-Dimensional Metal Nanomaterials: Synthesis, Properties, and Applications. Chem. Rev. 2018, 118, 6409-6455. [CrossRef]

92. Huang, Z.M.; Zhang, Y.Z.; Kotaki, M.; Ramakrishna, S. A review on polymer nanofibers by electrospinning and their applications in nanocomposites. Compos. Sci. Technol. 2003, 63, 2223-2253. [CrossRef]

93. Mazaheri, M.; Eslahi, N.; Ordikhani, F.; Tamjid, E.; Simchi, A. Nanomedicine applications in orthopedic medicine: State of the art. Int. J. Nanomed. 2015, 10, 6039-6054. [CrossRef]

94. Hosnedlova, B.; Kepinska, M.; Skalickova, S.; Fernandez, C.; Ruttkay-Nedecky, B.; Peng, Q.; Baron, M.; Melcova, M.; Opatrilova, R.; Zidkova, J.; et al. Nano-selenium and its nanomedicine applications: A critical review. Int. J. Nanomed. 2018, 13, 2107-2128. [CrossRef]

95. Cabral, H.; Miyata, K.; Osada, K.; Kataoka, K. Block Copolymer Micelles in Nanomedicine Applications. Chem. Rev. 2018, 118, 6844-6892. [CrossRef] [PubMed] 
96. Peer, D.; Karp, J.M.; Hong, S.; Farokhzad, O.C.; Margalit, R.; Langer, R. Nanocarriers as an emerging platform for cancer therapy. Nat. Nanotechnol. 2007, 2, 751-760. [CrossRef]

97. Song, N.; Lou, X.Y.; Ma, L.; Gao, H.; Yang, Y.W. Supramolecular nanotheranostics based on pillarenes. Theranostics 2019, 9, 3075-3093. [CrossRef] [PubMed]

98. Liu, Y.; Bhattarai, P.; Dai, Z.; Chen, X. Photothermal therapy and photoacoustic imaging: Via nanotheranostics in fighting cancer. Chem. Soc. Rev. 2019, 48, 2053-2108. [CrossRef] [PubMed]

99. Kunjachan, S.; Ehling, J.; Storm, G.; Kiessling, F.; Lammers, T. Noninvasive Imaging of Nanomedicines and Nanotheranostics: Principles, Progress, and Prospects. Chem. Rev. 2015, 115, 10907-10937. [CrossRef]

100. Aparicio-Blanco, J.; Torres-Suárez, A.I. Towards tailored management of malignant brain tumors with nanotheranostics. Acta Biomater. 2018, 73, 52-63. [CrossRef]

101. Roma-Rodrigues, C.; Pombo, I.; Raposo, L.; Pedrosa, P.; Fernandes, A.R.; Baptista, P.V. Nanotheranostics targeting the tumor microenvironment. Front. Bioeng. Biotechnol. 2019, 7, 1-18. [CrossRef] [PubMed]

102. Fan, J.X.; Zheng, D.W.; Mei, W.W.; Chen, S.; Chen, S.Y.; Cheng, S.X.; Zhang, X.Z. A Metal-Polyphenol Network Coated Nanotheranostic System for Metastatic Tumor Treatments. Small 2017, 13, 1-10. [CrossRef]

103. Cipolatti, E.P.; Valério, A.; Henriques, R.O.; Moritz, D.E.; Ninow, J.L.; Freire, D.M.G.; Manoel, E.A.; Fernandez-Lafuente, R.; De Oliveira, D. Nanomaterials for biocatalyst immobilization-state of the art and future trends. RSC Adv. 2016, 6, 104675-104692. [CrossRef]

104. Bilal, M.; Zhao, Y.; Rasheed, T.; Iqbal, H.M.N. Magnetic nanoparticles as versatile carriers for enzymes immobilization: A review. Int. J. Biol. Macromol. 2018, 120, 2530-2544. [CrossRef] [PubMed]

105. De Souza, M.C.M.; Dos Santos, K.P.; Freire, R.M.; Barreto, A.C.H.; Fechine, P.B.A.; Gonçalves, L.R.B. Production of flavor esters catalyzed by Lipase B from Candida antarctica immobilized on magnetic nanoparticles. Braz. J. Chem. Eng. 2017, 34, 681-690. [CrossRef]

106. Xing, X.; Jia, J.Q.; Zhang, J.F.; Zhou, Z.W.; Li, J.; Wang, N.; Yu, X.Q. CALB immobilized onto magnetic nanoparticles for efficient kinetic resolution of racemic secondary alcohols: Long-term stability and reusability. Molecules 2019, 24, 490. [CrossRef]

107. Neethirajan, S.; Ragavan, V.; Weng, X.; Chand, R. Biosensors for sustainable food engineering: Challenges and perspectives. Biosensors 2018, 8, 23. [CrossRef]

108. Dayem, A.A.; Hossain, M.K.; Lee, S.B.; Kim, K.; Saha, S.K.; Yang, G.M.; Choi, H.Y.; Cho, S.G. The role of reactive oxygen species (ROS) in the biological activities of metallic nanoparticles. Int. J. Mol. Sci. 2017, 18, 120. [CrossRef] [PubMed]

109. Singh, J.; Vishwakarma, K.; Ramawat, N.; Rai, P.; Singh, V.K.; Mishra, R.K.; Kumar, V.; Tripathi, D.K.; Sharma, S. Nanomaterials and microbes' interactions: A contemporary overview. 3 Biotech 2019, 9. [CrossRef] [PubMed]

110. Lv, M.; Liu, Y.; Geng, J.; Kou, X.; Xin, Z.; Yang, D. Engineering nanomaterials-based biosensors for food safety detection. Biosens. Bioelectron. 2018, 106, 122-128. [CrossRef]

111. Hosseini, M.; Khabbaz, H.; Dadmehr, M.; Ganjali, M.R.; Mohamadnejad, J. Aptamer-based Colorimetric and Chemiluminescence Detection of Aflatoxin B1 in Foods Samples. Acta Chim. Slov. 2015, 62, 721-728. [CrossRef] [PubMed]

112. Melo, A.; Amadeu, M.S.; Lancellotti, M.; De Hollanda, L.M.; Machado, D. The role of nanomaterials in cosmetics: National and international legislative aspects. Quim. Nova 2015, 38, 599-603. [CrossRef]

113. Fytianos, G.; Rahdar, A.; Kyzas, G.Z. Nanomaterials in cosmetics: Recent updates. Nanomaterials 2020, 10, 979. [CrossRef] [PubMed]

114. Srinivas, K. The current role of nanomaterials in cosmetics. J. Chem. Pharm. Res. 2016, 8, 906-914.

115. Cao, M.; Li, J.; Tang, J.; Chen, C.; Zhao, Y. Gold nanomaterials in consumer cosmetics nanoproducts: Analyses, characterization, and dermal safety assessment. Small 2016, 12, 5488-5496. [CrossRef]

116. Wu, W. Inorganic nanomaterials for printed electronics: A review. Nanoscale 2017, 9, 7342-7372. [CrossRef]

117. Lim, W.H.; Hamzah, A.; Ahmadi, M.T.; Ismail, R. Performance analysis of one dimensional BC2N for nanoelectronics applications. Phys. E Low Dimens. Syst. Nanostruct. 2018, 102, 33-38. [CrossRef]

118. Celis, A.; Nair, M.N.; Taleb-Ibrahimi, A.; Conrad, E.H.; Berger, C.; De Heer, W.A.; Tejeda, A. Graphene nanoribbons: Fabrication, properties and devices. J. Phys. D. Appl. Phys. 2016, 49, 143001. [CrossRef]

119. Saiz-Bretín, M.; Domínguez-Adame, F.; Malyshev, A.V. Twisted graphene nanoribbons as nonlinear nanoelectronic devices. Carbon N. Y. 2019, 149, 587-593. [CrossRef]

120. Gong, S.; Cheng, W. One-Dimensional Nanomaterials for Soft Electronics. Adv. Electron. Mater. 2017, 3. [CrossRef]

121. Della Pelle, F.; González, M.C.; Sergi, M.; Del Carlo, M.; Compagnone, D.; Escarpa, A. Gold Nanoparticles-based Extraction-Free Colorimetric Assay in Organic Media: An Optical Index for Determination of Total Polyphenols in Fat-Rich Samples. Anal. Chem. 2015, 87, 6905-6911. [CrossRef]

122. Putzbach, W.; Ronkainen, N. Immobilization Techniques in the Fabrication of Nanomaterial-Based Electrochemical Biosensors: A Review. Sensors 2013, 13, 4811-4840. [CrossRef]

123. Sanghavi, B.J.; Wolfbeis, O.S.; Hirsch, T.; Swami, N.S. Nanomaterial-based electrochemical sensing of neurological drugs and neurotransmitters. Microchim. Acta 2015, 182, 1-41. [CrossRef]

124. Niu, L.; Coleman, J.N.; Zhang, H.; Shin, H.; Chhowalla, M.; Zheng, Z. Production of Two-Dimensional Nanomaterials via Liquid-Based Direct Exfoliation. Small 2016, 12, 272-293. [CrossRef] 
125. Wang, X.; Chen, L.; Wang, L.; Fan, Q.; Pan, D.; Li, J.; Chi, F.; Xie, Y.; Yu, S.; Xiao, C.; et al. Synthesis of novel nanomaterials and their application in efficient removal of radionuclides. Sci. China Chem. 2019, 62, 933-967. [CrossRef]

126. Li, X.D.; Gao, J.Y.; Yang, Y.; Fang, H.Y.; Han, Y.J.; Wang, X.M.; Ge, W. Nanomaterials in the application of tumor vaccines: Advantages and disadvantages. Onco. Targets. Ther. 2013, 6, 629-634. [CrossRef]

127. Metkar, S.K.; Girigoswami, K. Diagnostic biosensors in medicine-A review. Biocatal. Agric. Biotechnol. 2019, 17, 271-283. [CrossRef]

128. Shandilya, R.; Bhargava, A.; Bunkar, N.; Tiwari, R.; Goryacheva, I.Y.; Mishra, P.K. Nanobiosensors: Point-of-care approaches for cancer diagnostics. Biosens. Bioelectron. 2019, 130, 147-165. [CrossRef]

129. Haes, A.J.; Van Duyne, R.P. A nanoscale optical biosensor: Sensitivity and selectivity of an approach based on the localized surface plasmon resonance spectroscopy of triangular silver nanoparticles. J. Am. Chem. Soc. 2002, 124, 10596-10604. [CrossRef]

130. Guo, L.J. Recent progress in nanoimprint technology and its applications. J. Phys. D Appl. Phys. 2004, 37, R123. [CrossRef]

131. Mokhtarzadeh, A.; Eivazzadeh-Keihan, R.; Pashazadeh, P.; Hejazi, M.; Gharaatifar, N.; Hasanzadeh, M.; Baradaran, B.; de la Guardia, M. Nanomaterial-based biosensors for detection of pathogenic virus. TrAC Trends Anal. Chem. 2017, 97, 445-457. [CrossRef]

132. Lan, L.; Yao, Y.; Ping, J.; Ying, Y. Recent advances in nanomaterial-based biosensors for antibiotics detection. Biosens. Bioelectron. 2017, 91, 504-514. [CrossRef]

133. Su, H.; Li, S.; Jin, Y.; Xian, Z.; Yang, D.; Zhou, W.; Mangaran, F.; Leung, F.; Sithamparanathan, G.; Kerman, K. Nanomaterial-based biosensors for biological detections. Adv. Health Care Technol. 2017, 3, 19-29. [CrossRef]

134. Ma, F.; Zhang, Q.; Zhang, C.Y. Nanomaterial-based biosensors for DNA methyltransferase assay. J. Mater. Chem. B 2020, 8, 3488-3501. [CrossRef] [PubMed]

135. Kuralay, F. Nanomaterials-Based Enzyme Biosensors for Electrochemical Applications: Recent Trends and Future Prospects. In New Developments in Nanosensors for Pharmaceutical Analysis; Elsevier: Amsterdam, The Netherlands, 2019; pp. 381-408; ISBN 9780128161449.

136. Tiwari, J.N.; Vij, V.; Kemp, K.C.; Kim, K.S. Engineered carbon-nanomaterial-based electrochemical sensors for biomolecules. ACS Nano 2016, 10, 46-80. [CrossRef]

137. Kim, J.H.; Jun, S.A.; Kwon, Y.; Ha, S.; Sang, B.I.; Kim, J. Enhanced electrochemical sensitivity of enzyme precipitate coating (EPC)-based glucose oxidase biosensors with increased free CNT loadings. Bioelectrochemistry 2015, 101, 114-119. [CrossRef]

138. Devasenathipathy, R.; Mani, V.; Chen, S.M.; Huang, S.T.; Huang, T.T.; Lin, C.M.; Hwa, K.Y.; Chen, T.Y.; Chen, B.J. Glucose biosensor based on glucose oxidase immobilized at gold nanoparticles decorated graphene-carbon nanotubes. Enzym. Microb. Technol. 2015, 78, 40-45. [CrossRef] [PubMed]

139. Venditti, I.; Hassanein, T.F.; Fratoddi, I.; Fontana, L.; Battocchio, C.; Rinaldi, F.; Carafa, M.; Marianecci, C.; Diociaiuti, M.; Agostinelli, E.; et al. Bioconjugation of gold-polymer core-shell nanoparticles with bovine serum amine oxidase for biomedical applications. Colloids Surf. B Biointerfaces 2015, 134, 314-321. [CrossRef]

140. Hushiarian, R.; Yusof, N.A.; Abdullah, A.H.; Ahmad, S.A.A.; Dutse, S.W. Facilitating the indirect detection of genomic DNA in an electrochemical DNA biosensor using magnetic nanoparticles and DNA ligase. Anal. Chem. Res. 2015, 6, 17-25. [CrossRef]

141. Khaksarinejad, R.; Mohsenifar, A.; Rahmani-Cherati, T.; Karami, R.; Tabatabaei, M. An Organophosphorus Hydrolase-Based Biosensor for Direct Detection of Paraoxon Using Silica-Coated Magnetic Nanoparticles. Appl. Biochem. Biotechnol. 2015, 176, 359-371. [CrossRef]

142. Bao, J.; Hou, C.; Chen, M.; Li, J.; Huo, D.; Yang, M.; Luo, X.; Lei, Y. Plant Esterase-Chitosan/Gold Nanoparticles-Graphene Nanosheet Composite-Based Biosensor for the Ultrasensitive Detection of Organophosphate Pesticides. J. Agric. Food Chem. 2015, 63, 10319-10326. [CrossRef]

143. Gumpu, M.B.; Nesakumar, N.; Sethuraman, S.; Krishnan, U.M.; Rayappan, J.B.B. Determination of Putrescine in Tiger Prawn Using an Amperometric Biosensor Based on Immobilization of Diamine Oxidase onto Ceria Nanospheres. Food Bioprocess. Technol. 2016, 9, 717-724. [CrossRef]

144. Borisova, B.; Sánchez, A.; Jiménez-Falcao, S.; Martín, M.; Salazar, P.; Parrado, C.; Pingarrón, J.M.; Villalonga, R. Reduced graphene oxide-carboxymethylcellulose layered with platinum nanoparticles/PAMAM dendrimer/magnetic nanoparticles hybrids. Application to the preparation of enzyme electrochemical biosensors. Sens. Actuators B Chem. 2016, 232, 84-90. [CrossRef]

145. Aigner, M.; Kalcher, K.; Macheroux, P.; Lienhart, W.D.; Wallner, S.; Edmondson, D.; Ortner, A. Determination of Total Monoamines in Rat Brain via Nanotubes Based Human Monoamine Oxidase B Biosensor. Electroanalysis 2017, 29, 367-373. [CrossRef]

146. Bäcker, M.; Koch, C.; Eiben, S.; Geiger, F.; Eber, F.; Gliemann, H.; Poghossian, A.; Wege, C.; Schöning, M.J. Tobacco mosaic virus as enzyme nanocarrier for electrochemical biosensors. Sens. Actuators B Chem. 2017, 238, 716-722. [CrossRef]

147. Caldas, E.M.; Novatzky, D.; Deon, M.; de Menezes, E.W.; Hertz, P.F.; Costa, T.M.H.; Arenas, L.T.; Benvenutti, E.V. Pore size effect in the amount of immobilized enzyme for manufacturing carbon ceramic biosensor. Microporous Mesoporous Mater. 2017, 247, 95-102. [CrossRef]

148. Yazdanparast, S.; Benvidi, A.; Abbasi, S.; Rezaeinasab, M. Enzyme-based ultrasensitive electrochemical biosensor using poly(Laspartic acid)/MWCNT bio-nanocomposite for xanthine detection: A meat freshness marker. Microchem. J. 2019, 149. [CrossRef]

149. Jirakunakorn, R.; Khumngern, S.; Choosang, J.; Thavarungkul, P.; Kanatharana, P.; Numnuam, A. Uric acid enzyme biosensor based on a screen-printed electrode coated with Prussian blue and modified with chitosan-graphene composite cryogel. Microchem. J. 2020, 154. [CrossRef] 
150. Kadian, S.; Arya, B.D.; Kumar, S.; Sharma, S.N.; Chauhan, R.P.; Srivastava, A.; Chandra, P.; Singh, S.P. Synthesis and Application of PHT-TiO 2 Nanohybrid for Amperometric Glucose Detection in Human Saliva Sample. Electroanalysis 2018, 30, $2793-2802$. [CrossRef]

151. Grinyte, R.; Barroso, J.; Möller, M.; Saa, L.; Pavlov, V. Microbead QD-ELISA: Microbead ELISA Using Biocatalytic Formation of Quantum Dots for Ultra High Sensitive Optical and Electrochemical Detection. ACS Appl. Mater. Interfaces 2016, 8, $29252-29260$. [CrossRef] [PubMed]

152. Silva, T.A.; Moraes, F.C.; Janegitz, B.C.; Fatibello-Filho, O. Electrochemical Biosensors Based on Nanostructured Carbon Black: A Review. J. Nanomater. 2017, 2017, 1-14. [CrossRef]

153. Senthamizhan, A.; Balusamy, B.; Uyar, T. Glucose sensors based on electrospun nanofibers: A review. Anal. Bioanal. Chem. 2016, 408, 1285-1306. [CrossRef]

154. Cinti, S.; Arduini, F.; Moscone, D.; Palleschi, G.; Gonzalez-Macia, L.; Killard, A.J. Cholesterol biosensor based on inkjet-printed Prussian blue nanoparticle-modified screen-printed electrodes. Sens. Actuators B Chem. 2015, 221, 187-190. [CrossRef]

155. Joshi, S.R.; Sharma, A.; Kim, G.H.; Jang, J. Low cost synthesis of reduced graphene oxide using biopolymer for influenza virus sensor. Mater. Sci. Eng. C 2020, 108, 110465. [CrossRef]

156. Sha, R.; Badhulika, S. Recent advancements in fabrication of nanomaterial based biosensors for diagnosis of ovarian cancer: A comprehensive review. Microchim. Acta 2020, 187. [CrossRef]

157. Klein, T.; Wang, W.; Yu, L.; Wu, K.; Boylan, K.L.M.; Vogel, R.I.; Skubitz, A.P.N.; Wang, J.P. Development of a multiplexed giant magnetoresistive biosensor array prototype to quantify ovarian cancer biomarkers. Biosens. Bioelectron. 2019, 126, 301-307. [CrossRef]

158. Samadi Pakchin, P.; Ghanbari, H.; Saber, R.; Omidi, Y. Electrochemical immunosensor based on chitosan-gold nanoparticle/carbon nanotube as a platform and lactate oxidase as a label for detection of CA125 oncomarker. Biosens. Bioelectron. 2018, 122, 68-74. [CrossRef]

159. Raghav, R.; Srivastava, S. Core-shell gold-silver nanoparticles based impedimetric immunosensor for cancer antigen CA125. Sens. Actuators B Chem. 2015, 220, 557-564. [CrossRef]

160. Paimard, G.; Shahlaei, M.; Moradipour, P.; Karamali, V.; Arkan, E. Impedimetric aptamer based determination of the tumor marker MUC1 by using electrospun core-shell nanofibers. Microchim. Acta 2020, 187. [CrossRef]

161. Fuertes, G.; Soto, I.; Vargas, M.; Valencia, A.; Sabattin, J.; Carrasco, R. Nanosensors for a monitoring system in intelligent and active packaging. J. Sens. 2016. [CrossRef]

162. Faalnouri, S.; Çimen, D.; Bereli, N.; Denizli, A. Surface Plasmon Resonance Nanosensors for Detecting Amoxicillin in Milk Samples with Amoxicillin Imprinted Poly(hydroxyethyl methacrylate-N-methacryloyl-(L)- glutamic acid). ChemistrySelect 2020, 5, 4761-4769. [CrossRef]

163. Wang, H.; Li, B.; Ding, F.; Ma, T. Improvement of properties of smart ink via chitin nanofiber and application as freshness indicator. Prog. Org. Coat. 2020, 149, 105921. [CrossRef]

164. Huang, S.; Zhang, Q.; Yao, H.; Wang, W.; Zhang, J.R.; Zhu, J.J. Quantitative Detection and Imaging of Multiple Biological Molecules in Living Cells for Cell Screening. ACS Sens. 2020, 5, 1149-1157. [CrossRef] [PubMed]

165. Xiang, Y.; Camarada, M.B.; Wen, Y.; Wu, H.; Chen, J.; Li, M.; Liao, X. Simple voltammetric analyses of ochratoxin A in food samples using highly-stable and anti-fouling black phosphorene nanosensor. Electrochim. Acta 2018, 282, 490-498. [CrossRef]

166. Gooch, J.; Daniel, B.; Parkin, M.; Frascione, N. Developing aptasensors for forensic analysis. TrAC Trends Anal. Chem. 2017, 94, 150-160. [CrossRef]

167. Tasis, D.; Tagmatarchis, N.; Bianco, A.; Prato, M. Chemistry of carbon nanotubes. Chem. Rev. 2006, 106, 1105-1136. [CrossRef] [PubMed]

168. Laurent, S.; Forge, D.; Port, M.; Roch, A.; Robic, C.; Vander Elst, L.; Muller, R.N. Magnetic iron oxide nanoparticles: Synthesis, stabilization, vectorization, physicochemical characterizations and biological applications. Chem. Rev. 2008, 108, $2064-2110$. [CrossRef] [PubMed]

169. Katz, E.; Willner, I. Integrated nanoparticle-biomolecule hybrid systems: Synthesis, properties, and applications. Angew. Chem. Int. Ed. 2004, 43, 6042-6108. [CrossRef]

170. Georgakilas, V.; Otyepka, M.; Bourlinos, A.B.; Chandra, V.; Kim, N.; Kemp, K.C.; Hobza, P.; Zboril, R.; Kim, K.S. Functionalization of graphene: Covalent and non-covalent approaches, derivatives and applications. Chem. Rev. 2012, 112, 6156-6214. [CrossRef]

171. Kozitsina, A.; Svalova, T.; Malysheva, N.; Okhokhonin, A.; Vidrevich, M.; Brainina, K. Sensors Based on Bio and Biomimetic Receptors in Medical Diagnostic, Environment, and Food Analysis. Biosensors 2018, 8, 35. [CrossRef]

172. López-Gallego, F.; Jackson, E.; Betancor, L. Heterogeneous Systems Biocatalysis: The Path to the Fabrication of Self-Sufficient Artificial Metabolic Cells. Chem. A Eur. J. 2017, 23, 17841-17849. [CrossRef]

173. Tian, K.; Prestgard, M.; Tiwari, A. A review of recent advances in nonenzymatic glucose sensors. Mater. Sci. Eng. C 2014, 41, 100-118. [CrossRef]

174. Soleymani, L.; Li, F. Mechanistic Challenges and Advantages of Biosensor Miniaturization into the Nanoscale. ACS Sens. 2017, 2, 458-467. [CrossRef]

175. Fathi, M.; Karim, M.; Khoigani, S.R.; Mosayebi, V. Use of Nanotechnology for Immobilization and Entrapment of Food Applicable Enzymes. In Bioactive Molecules in Food; Springer: Cham, Switzerland, 2019; pp. 2037-2061. 
176. Singhania, R.R.; Patel, A.K.; Thomas, L.; Goswami, M.; Giri, B.S.; Pandey, A. Industrial Enzymes; Elsevier: Amsterdam, The Netherlands, 2015; ISBN 9780444634535.

177. Porter, J.L.; Rusli, R.A.; Ollis, D.L. Directed Evolution of Enzymes for Industrial Biocatalysis. ChemBioChem 2016, 17, 197-203. [CrossRef]

178. Conix, S. Enzyme classification and the entanglement of values and epistemic standards. Stud. Hist. Philos. Sci. Part. A 2020. [CrossRef] [PubMed]

179. Bhalla, T.C.; Kumar, V.; Kumar, V.; Thakur, N. Savitri Nitrile Metabolizing Enzymes in Biocatalysis and Biotransformation. Appl. Biochem. Biotechnol. 2018, 185, 925-946. [CrossRef]

180. Liu, D.M.; Chen, J.; Shi, Y.P. Advances on methods and easy separated support materials for enzymes immobilization. TrAC Trends Anal. Chem. 2018, 102, 332-342. [CrossRef]

181. Kuah, E.; Toh, S.; Yee, J.; Ma, Q.; Gao, Z. Enzyme Mimics: Advances and Applications. Chem. A Eur. J. 2016, 22, 8404-8430. [CrossRef]

182. Drout, R.J.; Robison, L.; Farha, O.K. Catalytic applications of enzymes encapsulated in metal-organic frameworks. Coord. Chem. Rev. 2019, 381, 151-160. [CrossRef]

183. Garske, A.L.; Kapp, G.; Mcauliffe, J.C. Handbook of Industrial Chemistry and Biotechnology; Springer: Cham, Switzerland, 2017; ISBN 9783319522876.

184. Arsalan, A.; Younus, H. Enzymes and nanoparticles: Modulation of enzymatic activity via nanoparticles. Int. J. Biol. Macromol. 2018, 118, 1833-1847. [CrossRef] [PubMed]

185. Prasad, S.; Roy, I. Converting Enzymes into Tools of Industrial Importance. Recent Pat. Biotechnol. 2017, 12, 33-56. [CrossRef]

186. Hughes, G.; Lewis, J.C. Introduction: Biocatalysis in Industry. Chem. Rev. 2018, 118, 1-3. [CrossRef] [PubMed]

187. Singh, R.; Kumar, M.; Mittal, A.; Mehta, P.K. Microbial enzymes: Industrial progress in 21st century. 3 Biotech 2016, 6. [CrossRef] [PubMed]

188. Chapman, J.; Ismail, A.E.; Dinu, C.Z. Industrial applications of enzymes: Recent advances, techniques, and outlooks. Catalysts 2018, 8, 238. [CrossRef]

189. Sun, H.; Zhou, Y.; Ren, J.; Qu, X. Carbon Nanozymes: Enzymatic Properties, Catalytic Mechanism, and Applications. Angezw. Chem. Int. Ed. 2018, 57, 9224-9237. [CrossRef]

190. Zdarta, J.; Meyer, A.; Jesionowski, T.; Pinelo, M. A General Overview of Support Materials for Enzyme Immobilization: Characteristics, Properties, Practical Utility. Catalysts 2018, 8, 92. [CrossRef]

191. Fernandes, K.V.; Papadaki, A.; da Silva, J.A.C.; Fernandez-Lafuente, R.; Koutinas, A.A.; Freire, D.M.G. Enzymatic esterification of palm fatty-acid distillate for the production of polyol esters with biolubricant properties. Ind. Crop. Prod. 2018, 116, 90-96. [CrossRef]

192. Monteiro, R.R.C.; Neto, D.M.A.; Fechine, P.B.A.; Lopes, A.A.S.; Gonçalves, L.R.B.; dos Santos, J.C.S.; de Souza, M.C.M.; Fernandez-Lafuente, R. Ethyl Butyrate Synthesis Catalyzed by Lipases A and B from Candida antarctica Immobilized onto Magnetic Nanoparticles. Improvement of Biocatalysts' Performance under Ultrasonic Irradiation. Int. J. Mol. Sci. 2019, 20, 5807. [CrossRef] [PubMed]

193. Cavalcante, F.T.T.; Neto, F.S.; Rafael de Aguiar Falcão, I.; Erick da Silva Souza, J.; de Moura Junior, L.S.; da Silva Sousa, P.; Rocha, T.G.; de Sousa, I.G.; de Lima Gomes, P.H.; de Souza, M.C.M.; et al. Opportunities for improving biodiesel production via lipase catalysis. Fuel 2020, 288, 119577. [CrossRef]

194. Rueda, N.; dos Santos, J.C.S.; Ortiz, C.; Torres, R.; Barbosa, O.; Rodrigues, R.C.; Berenguer-Murcia, Á.; Fernandez-Lafuente, R. Chemical Modification in the Design of Immobilized Enzyme Biocatalysts: Drawbacks and Opportunities. Chem. Rec. 2016, 16, 1436-1455. [CrossRef]

195. Choi, J.M.; Han, S.S.; Kim, H.S. Industrial applications of enzyme biocatalysis: Current status and future aspects. Biotechnol. Adv. 2015, 33, 1443-1454. [CrossRef]

196. Da Fonseca, A.M.; Colares, R.P.; de Oliveira, M.M.; de Souza, M.C.M.; de Castro Monteiro, R.R.; dos Santos Araújo, R.; Amorim, A.V.; dos Santos, J.C.S.; Alcócer, J.C.A.; de Oliveira Pinto, O.R. Enzymatic Biocatalyst using enzymes from Pineapple (Ananas comosus) Peel Immobilized in Hydrogel Beads. Revista Eletrônica em Gestão Educação e Tecnologia Ambiental $2019,23,32$. [CrossRef]

197. Da Moreira, K.S.; de Oliveira, A.L.B.; Lourembergue, S.d.M., Jr.; Monteiro, R.R.C.; da Rocha, T.N.; Menezes, F.L.; Fechine, L.M.U.D.; Denardin, J.C.; Michea, S.; Freire, R.M.; et al. Lipase from Rhizomucor miehei Immobilized on Magnetic Nanoparticles: Performance in Fatty Acid Ethyl Ester (FAEE) Optimized Production by the Taguchi Method. Front. Bioeng. Biotechnol. 2020, 8, 1-17. [CrossRef]

198. Bezerra, R.M.; Monteiro, R.R.C.; Neto, D.M.A.; da Silva, F.F.M.; de Paula, R.C.M.; de Lemos, T.L.G.; Fechine, P.B.A.; Correa, M.A.; Bohn, F.; Gonçalves, L.R.B.; et al. A new heterofunctional support for enzyme immobilization: PEI functionalized $\mathrm{Fe}_{3} \mathrm{O}_{4} \mathrm{MNPs}_{\mathrm{s}}$ activated with divinyl sulfone. Application in the immobilization of lipase from Thermomyces lanuginosus. Enzym. Microb. Technol. 2020, 138, 109560. [CrossRef]

199. De Souza, T.C.; de Sousa Fonseca, T.; de Sousa Silva, J.; Lima, P.J.M.; Neto, C.A.C.G.; Monteiro, R.R.C.; Rocha, M.V.P.; de Mattos, M.C.; dos Santos, J.C.S.; Gonçalves, L.R.B. Modulation of lipase B from Candida antarctica properties via covalent immobilization on eco-friendly support for enzymatic kinetic resolution of rac-indanyl acetate. Bioprocess. Biosyst. Eng. 2020, 43, 2253-2268. [CrossRef] [PubMed] 
200. Eş, I.; Vieira, J.D.G.; Amaral, A.C. Principles, techniques, and applications of biocatalyst immobilization for industrial application. Appl. Microbiol. Biotechnol. 2015, 99, 2065-2082. [CrossRef]

201. Rueda, N.; Dos Santos, C.S.; Rodriguez, M.D.; Albuquerque, T.L.; Barbosa, O.; Torres, R.; Ortiz, C.; Fernandez-Lafuente, R. Reversible immobilization of lipases on octyl-glutamic agarose beads: A mixed adsorption that reinforces enzyme immobilization. J. Mol. Catal. B Enzym. 2016, 128, 10-18. [CrossRef]

202. Pinheiro, B.B.; Rios, N.S.; Rodríguez Aguado, E.; Fernandez-Lafuente, R.; Freire, T.M.; Fechine, P.B.A.; dos Santos, J.C.S.; Gonçalves, L.R.B. Chitosan activated with divinyl sulfone: A new heterofunctional support for enzyme immobilization. Application in the immobilization of lipase B from Candida antarctica. Int. J. Biol. Macromol. 2019, 130, 798-809. [CrossRef]

203. Rios, N.S.; Neto, D.M.A.; dos Santos, J.C.S.; Fechine, P.B.A.; Fernández-Lafuente, R.; Gonçalves, L.R.B. Comparison of the immobilization of lipase from Pseudomonas fluorescens on divinylsulfone or p-benzoquinone activated support. Int. J. Biol. Macromol. 2019, 134, 936-945. [CrossRef] [PubMed]

204. Rios, N.S.; Morais, E.G.; dos Santos Galvão, W.; Andrade Neto, D.M.; dos Santos, J.C.S.; Bohn, F.; Correa, M.A.; Fechine, P.B.A.; Fernandez-Lafuente, R.; Gonçalves, L.R.B. Further stabilization of lipase from Pseudomonas fluorescens immobilized on octyl coated nanoparticles via chemical modification with bifunctional agents. Int. J. Biol. Macromol. 2019, 141, 313-324. [CrossRef]

205. Pinheiro, M.P.; Monteiro, R.R.C.; Silva, F.F.M.; Lemos, T.L.G.; Fernandez-Lafuente, R.; Gonçalves, L.R.B.; dos Santos, J.C.S. Modulation of Lecitase properties via immobilization on differently activated Immobead-350: Stabilization and inversion of enantiospecificity. Process. Biochem. 2019, 87, 128-137. [CrossRef]

206. Moreira, K.S.; Moura, L.S.; Monteiro, R.R.C.; de Oliveira, A.L.B.; Valle, C.P.; Freire, T.M.; Fechine, P.B.A.; de Souza, M.C.M.; Fernandez-Lorente, G.; Guisan, J.M.; et al. Optimization of the Production of Enzymatic Biodiesel from Residual Babassu Oil (Orbignya sp.) via RSM. Catalysts 2020, 10, 414. [CrossRef]

207. Sirisha, V.L.; Jain, A.; Jain, A. Enzyme Immobilization: An Overview on Methods, Support Material, and Applications of Immobilized Enzymes, 1st ed.; Elsevier Inc.: Amsterdam, The Netherlands, 2016; Volume 79.

208. de Oliveira, U.M.F.; Lima de Matos, L.J.B.; de Souza, M.C.M.; Pinheiro, B.B.; dos Santos, J.C.S.; Gonçalves, L.R.B. Efficient biotechnological synthesis of flavor esters using a low-cost biocatalyst with immobilized Rhizomucor miehei lipase. Mol. Biol. Rep. 2019, 46, 597-608. [CrossRef] [PubMed]

209. dos Santos, J.C.S.; Garcia-Galan, C.; Rodrigues, R.C.; de Sant'Ana, H.B.; Gonçalves, L.R.B.; Fernandez-Lafuente, R. Stabilizing hyperactivated lecitase structures through physical treatment with ionic polymers. Process. Biochem. 2014, 49, 1511-1515. [CrossRef]

210. Mehta, J.; Bhardwaj, N.; Bhardwaj, S.K.; Kim, K.H.; Deep, A. Recent advances in enzyme immobilization techniques: Metalorganic frameworks as novel substrates. Coord. Chem. Rev. 2016, 322, 30-40. [CrossRef]

211. Vaghari, H.; Jafarizadeh-Malmiri, H.; Mohammadlou, M.; Berenjian, A.; Anarjan, N.; Jafari, N.; Nasiri, S. Application of magnetic nanoparticles in smart enzyme immobilization. Biotechnol. Lett. 2016, 38, 223-233. [CrossRef]

212. Boudrant, J.; Woodley, J.M.; Fernandez-Lafuente, R. Parameters necessary to define an immobilized enzyme preparation. Process. Biochem. 2020, 90, 66-80. [CrossRef]

213. Galvão, W.S.; Pinheiro, B.B.; Golçalves, L.R.B.; de Mattos, M.C.; Fonseca, T.S.; Regis, T.; Zampieri, D.; dos Santos, J.C.S.; Costa, L.S.; Correa, M.A.; et al. Novel nanohybrid biocatalyst: Application in the kinetic resolution of secondary alcohols. J. Mater. Sci. 2018, 53, 14121-14137. [CrossRef]

214. Meryam Sardar, R.A. Enzyme Immobilization: An Overview on Nanoparticles as Immobilization Matrix. Biochem. Anal. Biochem. 2015, 04. [CrossRef]

215. de Oliveira, U.M.F.; Lima de Matos, L.J.B.; de Souza, M.C.M.; Pinheiro, B.B.; dos Santos, J.C.S.; Gonçalves, L.R.B. Effect of the Presence of Surfactants and Immobilization Conditions on Catalysts' Properties of Rhizomucor miehei Lipase onto Chitosan. Appl. Biochem. Biotechnol. 2018, 184, 1263-1285. [CrossRef]

216. Pinheiro, M.P.; Rios, N.S.; de Fonseca, T.S.; de Bezerra, F.A.; Rodríguez-Castellón, E.; Fernandez-Lafuente, R.; Carlos de Mattos, M.; dos Santos, J.C.S.; Gonçalves, L.R.B. Kinetic resolution of drug intermediates catalyzed by lipase B from Candida antarctica immobilized on immobead-350. Biotechnol. Prog. 2018, 34, 878-889. [CrossRef] [PubMed]

217. Melo, A.D.Q.; Silva, F.F.M.; Dos Santos, J.C.S.; Fernández-Lafuente, R.; Lemos, T.L.G.; Dias Filho, F.A. Synthesis of benzyl acetate catalyzed by lipase immobilized in nontoxic chitosan-polyphosphate beads. Molecules 2017, 22, 2165. [CrossRef] [PubMed]

218. Poorakbar, E.; Shafiee, A.; Saboury, A.A.; Rad, B.L.; Khoshnevisan, K.; Ma'mani, L.; Derakhshankhah, H.; Ganjali, M.R.; Hosseini, M. Synthesis of magnetic gold mesoporous silica nanoparticles core shell for cellulase enzyme immobilization: Improvement of enzymatic activity and thermal stability. Process. Biochem. 2018, 71, 92-100. [CrossRef]

219. Lima, G.V.; da Silva, M.R.; de Sousa Fonseca, T.; de Lima, L.B.; de Oliveira, M.d.C.F.; de Lemos, T.L.G.; Zampieri, D.; dos Santos, J.C.S.; Rios, N.S.; Gonçalves, L.R.B.; et al. Chemoenzymatic synthesis of (S)-Pindolol using lipases. Appl. Catal. A Gen. 2017, 546, 7-14. [CrossRef]

220. Dos Santos, J.C.S.; Bonazza, H.L.; de Matos, L.J.B.L.; Carneiro, E.A.; Barbosa, O.; Fernandez-Lafuente, R.; Gonçalves, L.R.B.; de Sant' Ana, H.B.; Santiago-Aguiar, R.S. Immobilization of CALB on activated chitosan: Application to enzymatic synthesis in supercritical and near-critical carbon dioxide. Biotechnol. Rep. 2017, 14, 16-26. [CrossRef] 
221. Rios, N.S.; Pinheiro, M.P.; dos Santos, J.C.S.; Fonseca, T.d.S.; Lima, L.D.; de Mattos, M.C.; Freire, D.M.G.; da Silva, I.J.; Rodríguez-Aguado, E.; Gonçalves, L.R.B. Strategies of covalent immobilization of a recombinant Candida antarctica lipase B on pore-expanded SBA-15 and its application in the kinetic resolution of (R,S)-Phenylethyl acetate. J. Mol. Catal. B Enzym. 2016, 133, 246-258. [CrossRef]

222. Bezerra, R.M.; Neto, D.M.A.; Galvão, W.S.; Rios, N.S.; Carvalho, A.C.L.d.M.; Correa, M.A.; Bohn, F.; Fernandez-Lafuente, R.; Fechine, P.B.A.; de Mattos, M.C.; et al. Design of a lipase-nano particle biocatalysts and its use in the kinetic resolution of medicament precursors. Biochem. Eng. J. 2017, 125, 104-115. [CrossRef]

223. Mohamad, N.R.; Marzuki, N.H.C.; Buang, N.A.; Huyop, F.; Wahab, R.A. An overview of technologies for immobilization of enzymes and surface analysis techniques for immobilized enzymes. Biotechnol. Biotechnol. Equip. 2015, 29, 205-220. [CrossRef]

224. Zdarta, J.; Meyer, A.S.; Jesionowski, T.; Pinelo, M. Developments in support materials for immobilization of oxidoreductases: A comprehensive review. Adv. Colloid Interface Sci. 2018, 258, 1-20. [CrossRef]

225. Virgen-Ortíz, J.J.; Dos Santos, J.C.S.; Berenguer-Murcia, Á.; Barbosa, O.; Rodrigues, R.C.; Fernandez-Lafuente, R. Polyethylenimine: A very useful ionic polymer in the design of immobilized enzyme biocatalysts. J. Mater. Chem. B 2017, 5, 7461-7490. [CrossRef]

226. Nadar, S.S.; Rathod, V.K. Magnetic-metal organic framework (magnetic-MOF): A novel platform for enzyme immobilization and nanozyme applications. Int. J. Biol. Macromol. 2018, 120, 2293-2302. [CrossRef]

227. Santos, M.P.F.; Brito, M.J.P.; Junior, E.C.S.; Bonomo, R.C.F.; Veloso, C.M. Pepsin immobilization on biochar by adsorption and covalent binding, and its application for hydrolysis of bovine casein. J. Chem. Technol. Biotechnol. 2019, 94, 1982-1990. [CrossRef]

228. Reis, C.L.B.; de Sousa, E.Y.A.; de França Serpa, J.; Oliveira, R.C.; Dos Santos, J.C.S. Design of immobilized enzyme biocatalysts: Drawbacks and opportunities. Quim. Nova 2019, 42, 768-783. [CrossRef]

229. Fopase, R.; Paramasivam, S.; Kale, P.; Paramasivan, B. Strategies, challenges and opportunities of enzyme immobilization on porous silicon for biosensing applications. J. Environ. Chem. Eng. 2020, 8, 104266. [CrossRef]

230. Lin, J.; Wen, Q.; Chen, S.; Le, X.; Zhou, X.; Huang, L. Synthesis of amine-functionalized Fe3O4@C nanoparticles for laccase immobilization. Int. J. Biol. Macromol. 2017, 96, 377-383. [CrossRef] [PubMed]

231. Sneha, H.P.; Beulah, K.C.; Murthy, P.S. Enzyme Immobilization Methods and Applications in the Food Industry; Elsevier Inc.: Amsterdam, The Netherlands, 2018; ISBN 9780128132807.

232. Bashir, N.; Sood, M.; Bandral, J.D. Enzyme immobilization and its applications in food processing: A review. Int. J. Chem. Stud. 2020, 8, 254-261. [CrossRef]

233. Thangaraj, B.; Solomon, P.R. Immobilization of Lipases-A Review. Part I: Enzyme Immobilization. ChemBioEng Rev. 2019, 6, 157-166. [CrossRef]

234. Strakosas, X.; Huerta, M.; Donahue, M.J.; Hama, A.; Pappa, A.M.; Ferro, M.; Ramuz, M.; Rivnay, J.; Owens, R.M. Catalytically enhanced organic transistors for in vitro toxicology monitoring through hydrogel entrapment of enzymes. J. Appl. Polym. Sci. 2017, 134, 1-7. [CrossRef]

235. Grollmisch, A.; Kragl, U.; Großeheilmann, J. Enzyme Immobilization in Polymerized Ionic Liquids-based Hydrogels for Active and Reusable Biocatalysts. SynOpen 2018, 02, 0192-0199. [CrossRef]

236. Adnan, M.; Li, K.; Xu, L.; Yan, Y. X-shaped zif-8 for immobilization Rhizomucor miehei lipase via encapsulation and its application toward biodiesel production. Catalysts 2018, 8, 96. [CrossRef]

237. Cacicedo, M.L.; Manzo, R.M.; Municoy, S.; Bonazza, H.L.; Islan, G.A.; Desimone, M.; Bellino, M.; Mammarella, E.J.; Castro, G.R Immobilized Enzymes and Their Applications. In Advances in Enzyme Technology; Elsevier: Amsterdam, The Netherlands, 2019; pp. 169-200; ISBN 9780444641144.

238. Muguruma, H. Biosensors: Enzyme Immobilization Chemistry; Elsevier: Amsterdam, The Netherlands, 2018 ; ISBN 9780128098943.

239. Xu, L.; Ke, C.; Huang, Y.; Yan, Y. Immobilized Aspergillus niger lipase with $\mathrm{SiO}_{2}$ nanoparticles in sol-gel materials. Catalysts 2016, 6, 149. [CrossRef]

240. Chung, Y.; Christwardana, M.; Tannia, D.C.; Kim, K.J.; Kwon, Y. Biocatalyst including porous enzyme cluster composite immobilized by two-step crosslinking and its utilization as enzymatic biofuel cell. J. Power Sources 2017, 360, 172-179. [CrossRef]

241. Thompson, M.P.; Peñafiel, I.; Cosgrove, S.C.; Turner, N.J. Biocatalysis Using Immobilized Enzymes in Continuous Flow for the Synthesis of Fine Chemicals. Org. Process. Res. Dev. 2019, 23, 9-18. [CrossRef]

242. Velasco-Lozano, S.; López-Gallego, F.; Mateos-Díaz, J.C.; Favela-Torres, E. Cross-linked enzyme aggregates (CLEA) in enzyme improvement-A review. Biocatalysis 2016, 1, 166-177. [CrossRef]

243. Voběrková, S.; Solčány, V.; Vršanská, M.; Adam, V. Immobilization of ligninolytic enzymes from white-rot fungi in cross-linked aggregates. Chemosphere 2018, 202, 694-707. [CrossRef]

244. Wang, S.; Zheng, D.; Yin, L.; Wang, F. Preparation, activity and structure of cross-linked enzyme aggregates (CLEAs) with nanoparticle. Enzym. Microb. Technol. 2017, 107, 22-31. [CrossRef]

245. Tavernini, L.; Ottone, C.; Illanes, A.; Wilson, L. Entrapment of enzyme aggregates in chitosan beads for aroma release in white wines. Int. J. Biol. Macromol. 2020, 154, 1082-1090. [CrossRef] [PubMed]

246. Doraiswamy, N.; Sarathi, M.; Pennathur, G. Cross-linked esterase aggregates (CLEAs) using nanoparticles as immobilization matrix. Prep. Biochem. Biotechnol. 2019, 49, 270-278. [CrossRef]

247. Bilal, M.; Asgher, M.; Cheng, H.; Yan, Y.; Iqbal, H.M.N. Multi-point enzyme immobilization, surface chemistry, and novel platforms: A paradigm shift in biocatalyst design. Crit. Rev. Biotechnol. 2019, 39, 202-219. [CrossRef] [PubMed] 
248. Asal, M.; Özen, Ö.; Şahinler, M.; Baysal, H.T.; Polatoğlu, İ. An overview of biomolecules, immobilization methods and support materials of biosensors. Sens. Rev. 2019, 39, 377-386. [CrossRef]

249. Mehrasbi, M.R.; Mohammadi, J.; Peyda, M.; Mohammadi, M. Covalent immobilization of Candida antarctica lipase on core-shell magnetic nanoparticles for production of biodiesel from waste cooking oil. Renew. Energy 2017, 101, 593-602. [CrossRef]

250. Carvalho, Y.; Almeida, J.M.A.R.; Romano, P.N.; Farrance, K.; Demma Carà, P.; Pereira, N.; Lopez-Sanchez, J.A.; Sousa-Aguiar, E.F. Nanosilicalites as Support for $\beta$-Glucosidases Covalent Immobilization. Appl. Biochem. Biotechnol. 2017, 182, 1619-1629. [CrossRef]

251. Lonappan, L.; Liu, Y.; Rouissi, T.; Pourcel, F.; Brar, S.K.; Verma, M.; Surampalli, R.Y. Covalent immobilization of laccase on citric acid functionalized micro-biochars derived from different feedstock and removal of diclofenac. Chem. Eng. J. 2018, 351, 985-994. [CrossRef]

252. Osuna, Y.; Sandoval, J.; Saade, H.; López, R.G.; Martinez, J.L.; Colunga, E.M.; de la Cruz, G.; Segura, E.P.; Arévalo, F.J.; Zon, M.A.; et al. Immobilization of Aspergillus niger lipase on chitosan-coated magnetic nanoparticles using two covalent-binding methods. Bioprocess. Biosyst. Eng. 2015, 38. [CrossRef] [PubMed]

253. Dos Santos, J.C.S.; Rueda, N.; Barbosa, O.; Fernández-Sánchez, J.F.; Medina-Castillo, A.L.; Ramón-Márquez, T.; Arias-Martos, M.C.; Millán-Linares, M.C.; Pedroche, J.; Yust, M.D.M.; et al. Characterization of supports activated with divinyl sulfone as a tool to immobilize and stabilize enzymes via multipoint covalent attachment. Application to chymotrypsin. RSC Adv. 2015, 5, 20639-20649. [CrossRef]

254. Dos Santos, J.C.S.; Barbosa, O.; Ortiz, C.; Berenguer-Murcia, A.; Rodrigues, R.C.; Fernandez-Lafuente, R. Importance of the Support Properties for Immobilization or Purification of Enzymes. ChemCatChem 2015, 7, 2413-2432. [CrossRef]

255. Gupta, S.; Murthy, C.N.; Prabha, C.R. Recent advances in carbon nanotube based electrochemical biosensors. Int. J. Biol. Macromol. 2018, 108, 687-703. [CrossRef]

256. Gerard, M.; Chaubey, A.; Malhotra, B.D. Application of conducting polymers to biosensors. Biosens. Bioelectron. 2002, 17, 345-359. [CrossRef]

257. Saha, K.; Agasti, S.S.; Kim, C.; Li, X.; Rotello, V.M. Gold nanoparticles in chemical and biological sensing. Chem. Rev. 2012, 112, 2739-2779. [CrossRef]

258. Daniel, M.C.; Astruc, D. Gold nanoparticles: Assembly, supramolecularchemistry, quantum-size-related properties, and applications toward. Chem. Rev. 2004, 104, 293-346. [CrossRef]

259. Krajewska, B. Application of chitin- and chitosan-based materials for enzyme immobilizations: A review. Enzym. Microb. Technol. 2004, 35, 126-139. [CrossRef]

260. Wei, H.; Wang, E. Nanomaterials with enzyme-like characteristics (nanozymes): Next-generation artificial enzymes. Chem. Soc. Rev. 2013, 42, 6060-6093. [CrossRef]

261. Wilson, R.; Turner, A.P.F. Glucose oxidase: An ideal enzyme. Biosens. Bioelectron. 1992, 7, 165-185. [CrossRef]

262. Katz, E.; Willner, I. Probing biomolecular interactions at conductive and semiconductive surfaces by impedance spectroscopy: Routes to impedimetric immunosensors, DNA-sensors, and enzyme biosensors. Electroanalysis 2003, 15, 913-947. [CrossRef]

263. Gandomkar, S.; Habibi, Z.; Mohammadi, M.; Yousefi, M.; Salimi, S. Enantioselective resolution of racemic ibuprofen esters using different lipases immobilized on epoxy-functionalized silica. Biocatal. Agric. Biotechnol. 2015, 4, 550-554. [CrossRef]

264. Hartmann, M. Ordered mesoporous materials for bioadsorption and biocatalysis. Chem. Mater. 2005, 17, 4577-4593. [CrossRef]

265. Willner, I.; Katz, E. Integration of layered redox proteins and conductive supports for bioelectronic applications. Angew. Chem. Int. Ed. 2000, 39, 1180-1218. [CrossRef]

266. Kuila, T.; Bose, S.; Khanra, P.; Mishra, A.K.; Kim, N.H.; Lee, J.H. Recent advances in graphene-based biosensors. Biosens. Bioelectron. 2011, 26, 4637-4648. [CrossRef] [PubMed]

267. Kim, J.; Grate, J.W.; Wang, P. Nanostructures for enzyme stabilization. Chem. Eng. Sci. 2006, 61, 1017-1026. [CrossRef]

268. Vidotti, M.; Carvalhal, R.F.; Mendes, R.K.; Ferreira, D.C.M.; Kubota, L.T. Biosensors based on gold nanostructures. J. Braz. Chem. Soc. 2011, 22, 3-20. [CrossRef]

269. Piotrowski, P.; Jakubow, K.; Kowalewska, B.; Kaim, A. Dioxygen insensitive C70/AuNPs hybrid system for rapid and quantitative glucose biosensing. RSC Adv. 2017, 7, 45634-45640. [CrossRef]

270. Gómez-Anquela, C.; García-Mendiola, T.; Abad, J.M.; Pita, M.; Pariente, F.; Lorenzo, E. Scaffold electrodes based on thioctic acid-capped gold nanoparticles coordinated Alcohol Dehydrogenase and Azure A films for high performance biosensor. Bioelectrochemistry 2015, 106, 335-342. [CrossRef]

271. Luo, X.; Morrin, A.; Killard, A.J.; Smyth, M.R. Application of nanoparticles in electrochemical sensors and biosensors. Electroanalysis 2006, 18, 319-326. [CrossRef]

272. Chen, A.; Chatterjee, S. Nanomaterials based electrochemical sensors for biomedical applications. Chem. Soc. Rev. 2013, 42, 5425-5438. [CrossRef]

273. Bollella, P.; Gorton, L. Enzyme based amperometric biosensors. Curr. Opin. Electrochem. 2018, 10, 157-173. [CrossRef]

274. Attar, A.; Cubillana-Aguilera, L.; Naranjo-Rodríguez, I.; de Cisneros, J.L.H.H.; Palacios-Santander, J.M.; Amine, A. Amperometric inhibition biosensors based on horseradish peroxidase and gold sononanoparticles immobilized onto different electrodes for cyanide measurements. Bioelectrochemistry 2015, 101, 84-91. [CrossRef] 
275. Zhang, X.R.; Zhang, Y.; Chen, F.T.; Li, Y.; Zhang, S.S. Visual detection of single-nucleotide polymorphisms and DNA methyltransferase based on cation-exchange of CuS nanoparticles and click chemistry of functionalized gold nanoparticles. Chem. Commun. 2016, 52, 13261-13264. [CrossRef]

276. Wee, Y.; Park, S.; Kwon, Y.H.; Ju, Y.; Yeon, K.M.; Kim, J. Tyrosinase-immobilized CNT based biosensor for highly-sensitive detection of phenolic compounds. Biosens. Bioelectron. 2019, 132, 279-285. [CrossRef]

277. Mohankumar, P.; Ajayan, J.; Mohanraj, T.; Yasodharan, R. Recent developments in biosensors for healthcare and biomedical applications: A review. Measurement 2021, 167, 108293. [CrossRef]

278. Mishra, R.K.; Rajakumari, R. Nanobiosensors for Biomedical Application. In Characterization and Biology of Nanomaterials for Drug Delivery; Mohapatra, S., Ranjan, S., Dasgupta, N., Mishra, R., Thomas, S., Eds.; Elsevier: Amsterdam, The Netherlands, 2019; pp. 1-23; ISBN 9780128140321.

279. Singh, R.P.; Oh, B.-K.K.; Choi, J.-W.W. Application of peptide nucleic acid towards development of nanobiosensor arrays. Bioelectrochemistry 2010, 79, 153-161. [CrossRef] [PubMed]

280. Saei, A.A.; Dolatabadi, J.E.N.; Najafi-Marandi, P.; Abhari, A.; de la Guardia, M. Electrochemical biosensors for glucose based on metal nanoparticles. TrAC Trends Anal. Chem. 2013, 42, 216-227. [CrossRef]

281. Sawani, S.; Siddiqui, A.R.; Azam, S.I.; Humayun, K.; Ahmed, A.; Habib, A.; Naz, S.; Tufail, M.; Iqbal, R. Lifestyle changes and glycemic control in type 1 diabetes mellitus: A trial protocol with factorial design approach. Trials 2020, 21, 346. [CrossRef]

282. Martín-Timón, I. Type 2 diabetes and cardiovascular disease: Have all risk factors the same strength? World J. Diabetes 2014, 5, 444. [CrossRef] [PubMed]

283. Si, P.; Huang, Y.; Wang, T.; Ma, J. Nanomaterials for electrochemical non-enzymatic glucose biosensors. RSC Adv. 2013, 3, 3487-3502. [CrossRef]

284. Makaram, P.; Owens, D.; Aceros, J. Trends in Nanomaterial-Based Non-Invasive Diabetes Sensing Technologies. Diagnostics 2014, 4, 27-46. [CrossRef] [PubMed]

285. Witkowska Nery, E.; Kundys, M.; Jeleń, P.S.; Jönsson-Niedziółka, M. Electrochemical Glucose Sensing: Is There Still Room for Improvement? Anal. Chem. 2016, 88, 11271-11282. [CrossRef] [PubMed]

286. Yoo, E.H.; Lee, S.Y. Glucose biosensors: An overview of use in clinical practice. Sensors 2010, 10, 4558-4576. [CrossRef] [PubMed]

287. Ashrafi, A.M.; Sýs, M.; Sedláčková, E.; Shaaban Farag, A.; Adam, V.; Přibyl, J.; Richtera, L. Application of the enzymatic electrochemical biosensors for monitoring non-competitive inhibition of enzyme activity by heavy metals. Sensors 2019, 19, 2939. [CrossRef] [PubMed]

288. Ridhuan, N.S.; Abdul Razak, K.; Lockman, Z. Fabrication and Characterization of Glucose Biosensors by Using Hydrothermally Grown ZnO Nanorods. Sci. Rep. 2018, 8, 13722. [CrossRef] [PubMed]

289. Bankar, S.B.; Bule, M.V.; Singhal, R.S.; Ananthanarayan, L. Glucose oxidase-An overview. Biotechnol. Adv. 2009, $27,489-501$. [CrossRef]

290. Wang, H.-C.; Chang, F.-Y.; Tsai, T.-M. Design, fabrication, and feasibility analysis of a colorimetric detection system with a smartphone for self-monitoring blood glucose. J. Biomed. Opt. 2019, 24, 1. [CrossRef]

291. Viswanathan, S.; Li, P.; Choi, W.; Filipek, S.; Balasubramaniam, T.A.; Renugopalakrishnan, V. Protein-Carbon Nanotube Sensors. In Methods in Enzymology; Düzgüneş, N., Ed.; Elsevier: Amsterdam, The Netherlands, 2012; Volume 509, pp. 165-194; ISBN 0076-6879.

292. Suzuki, N.; Lee, J.; Loew, N.; Takahashi-Inose, Y.; Okuda-Shimazaki, J.; Kojima, K.; Mori, K.; Tsugawa, W.; Sode, K. Engineered Glucose Oxidase Capable of Quasi-Direct Electron Transfer after a Quick-and-Easy Modification with a Mediator. Int. J. Mol. Sci. 2020, 21, 1137. [CrossRef] [PubMed]

293. Kornecki, J.F.; Carballares, D.; Tardioli, P.W.; Rodrigues, R.C.; Berenguer-Murcia, Á.; Alcántara, A.R.; Fernandez-Lafuente, R. Enzyme production of D-gluconic acid and glucose oxidase: Successful tales of cascade reactions. Catal. Sci. Technol. 2020, 10, 5740-5771. [CrossRef]

294. Milton, R.D.; Giroud, F.; Thumser, A.E.; Minteer, S.D.; Slade, R.C.T. Hydrogen peroxide produced by glucose oxidase affects the performance of laccase cathodes in glucose/oxygen fuel cells: FAD-dependent glucose dehydrogenase as a replacement. Phys. Chem. Chem. Phys. 2013, 15, 19371. [CrossRef] [PubMed]

295. Zhang, W.; Li, G. Third-Generation Biosensors Based on the Direct Electron Transfer of Proteins. Anal. Sci. 2004, 20, 603-609. [CrossRef]

296. Lata, K.; Dhull, V.; Hooda, V. Fabrication and Optimization of ChE/ChO/HRP-AuNPs/c-MWCNTs Based Silver Electrode for Determining Total Cholesterol in Serum. Biochem. Res. Int. 2016, 2016, 1-11. [CrossRef]

297. Huang, Y.; Cui, L.; Xue, Y.; Zhang, S.; Zhu, N.; Liang, J.; Li, G. Ultrasensitive cholesterol biosensor based on enzymatic silver deposition on gold nanoparticles modified screen-printed carbon electrode. Mater. Sci. Eng. C 2017, 77, 1-8. [CrossRef]

298. Dervisevic, M.; Çevik, E.; Şenel, M.; Nergiz, C.; Abasiyanik, M.F. Amperometric cholesterol biosensor based on reconstituted cholesterol oxidase on boronic acid functional conducting polymers. J. Electroanal. Chem. 2016, 776, 18-24. [CrossRef]

299. Ghosh, S.; Ahmad, R.; Gautam, V.K.; Khare, S.K. Cholesterol-oxidase-magnetic nanobioconjugates for the production of 4cholesten-3-one and 4-cholesten-3, 7-dione. Bioresour. Technol. 2018, 254, 91-96. [CrossRef]

300. Shukla, S.K.; Turner, A.P.F.; Tiwari, A. Cholesterol Oxidase Functionalised Polyaniline/Carbon Nanotube Hybrids for an Amperometric Biosensor. J. Nanosci. Nanotechnol. 2015, 15, 3373-3377. [CrossRef] 
301. Umar, A.; Rahman, M.M.; Al-Hajry, A.; Hahn, Y.B. Highly-sensitive cholesterol biosensor based on well-crystallized flower-shaped ZnO nanostructures. Talanta 2009, 78, 284-289. [CrossRef]

302. Devi, S.; Kanwar, S.S. Cholesterol Oxidase: Source, Properties and Applications. Insights Enzym. Res. 2018, 1. [CrossRef]

303. Perillo, B.; Di Donato, M.; Pezone, A.; Di Zazzo, E.; Giovannelli, P.; Galasso, G.; Castoria, G.; Migliaccio, A. ROS in cancer therapy: The bright side of the moon. Exp. Mol. Med. 2020, 52, 192-203. [CrossRef]

304. Liu, J.; Xian, G.; Li, M.; Zhang, Y.; Yang, M.; Yu, Y.; Lv, H.; Xuan, S.; Lin, Y.; Gao, L. Cholesterol oxidase from Bordetella species promotes irreversible cell apoptosis in lung adenocarcinoma by cholesterol oxidation. Cell Death Dis. 2014, 5, e1372. [CrossRef] [PubMed]

305. Reddy, K.B. MicroRNA (miRNA) in cancer. Cancer Cell Int. 2015, 15, 4-9. [CrossRef] [PubMed]

306. Acunzo, M.; Romano, G.; Wernicke, D.; Croce, C.M. MicroRNA and cancer-A brief overview. Adv. Biol. Regul. 2015, 57, 1-9. [CrossRef] [PubMed]

307. Ohtsuka, M.; Ling, H.; Doki, Y.; Mori, M.; Calin, G. MicroRNA Processing and Human Cancer. J. Clin. Med. 2015, 4, 1651-1667. [CrossRef] [PubMed]

308. Rupaimoole, R.; Slack, F.J. MicroRNA therapeutics: Towards a new era for the management of cancer and other diseases. Nat. Rev. Drug Discov. 2017, 16, 203-222. [CrossRef]

309. Krishnan, S.K.; Singh, E.; Singh, P.; Meyyappan, M.; Nalwa, H.S. A review on graphene-based nanocomposites for electrochemical and fluorescent biosensors. RSC Adv. 2019, 9, 8778-8881. [CrossRef]

310. Cardoso, A.R.; Moreira, F.T.C.; Fernandes, R.; Sales, M.G.F. Novel and simple electrochemical biosensor monitoring attomolar levels of miRNA-155 in breast cancer. Biosens. Bioelectron. 2016, 80, 621-630. [CrossRef]

311. Hu, T.; Zhang, L.; Wen, W.; Zhang, X.; Wang, S. Enzyme catalytic amplification of miRNA-155 detection with graphene quantum dot-based electrochemical biosensor. Biosens. Bioelectron. 2016, 77, 451-456. [CrossRef] [PubMed]

312. Deng, D.; Hao, Y.; Xue, J.; Liu, X.; Xu, X.; Liu, L. A colorimetric enzyme-linked immunosorbent assay with CuO nanoparticles as signal labels based on the growth of gold nanoparticles in situ. Nanomaterials 2019, 9, 4. [CrossRef]

313. Gao, Y.; Zhou, Y.; Chandrawati, R. Metal and Metal Oxide Nanoparticles to Enhance the Performance of Enzyme-Linked Immunosorbent Assay (ELISA). ACS Appl. Nano Mater. 2020, 3, 1-21. [CrossRef]

314. Gao, L.; Yang, Q.; Wu, P.; Li, F. Recent advances in nanomaterial-enhanced enzyme-linked immunosorbent assays. Analyst 2020, 145, 4069-4078. [CrossRef] [PubMed]

315. Jiao, L.; Zhang, L.; Du, W.; Li, H.; Yang, D.; Zhu, C. Au@Pt nanodendrites enhanced multimodal enzyme-linked immunosorbent assay. Nanoscale 2019, 11,8798-8802. [CrossRef]

316. Billingsley, M.M.; Riley, R.S.; Day, E.S. Antibody-nanoparticle conjugates to enhance the sensitivity of ELISA-based detection methods. PLoS ONE 2017, 12, e0177592. [CrossRef]

317. Rathee, K.; Dhull, V.; Dhull, R.; Singh, S. Biosensors based on electrochemical lactate detection: A comprehensive review. Biochem. Biophys. Rep. 2016, 5, 35-54. [CrossRef]

318. Teymourian, H.; Salimi, A.; Khezrian, $\mathrm{S} . \mathrm{Fe}_{3} \mathrm{O}_{4}$ magnetic nanoparticles/reduced graphene oxide nanosheets as a novel electrochemical and bioeletrochemical sensing platform. Biosens. Bioelectron. 2013, 49, 1-8. [CrossRef]

319. Dungchai, W.; Chailapakul, O.; Henry, C.S. Electrochemical detection for paper-based microfluidics. Anal. Chem. 2009, 81, 5821-5826. [CrossRef] [PubMed]

320. Ricci, F.; Palleschi, G. Sensor and biosensor preparation, optimisation and applications of Prussian Blue modified electrodes. Biosens. Bioelectron. 2005, 21, 389-407. [CrossRef]

321. Jena, B.K.; Raj, C.R. Electrochemical biosensor based on integrated assembly of dehydrogenase enzymes and gold nanoparticles. Anal. Chem. 2006, 78, 6332-6339. [CrossRef] [PubMed]

322. Bravo, I.; Gutiérrez-Sánchez, C.; García-Mendiola, T.; Revenga-Parra, M.; Pariente, F.; Lorenzo, E. Enhanced Performance of Reagent-Less Carbon Nanodots Based Enzyme Electrochemical Biosensors. Sensors 2019, 19, 5576. [CrossRef] [PubMed]

323. Batra, B.; Narwal, V.; Pundir, C.S. An amperometric lactate biosensor based on lactate dehydrogenase immobilized onto graphene oxide nanoparticles-modified pencil graphite electrode. Eng. Life Sci. 2016, 16, 786-794. [CrossRef]

324. Bravo, I.; Revenga-Parra, M.; Weber, K.; Popp, J.; Pariente, F.; Lorenzo, E. One-step reduced/quinone functionalized graphene oxide as reagentless lactate biosensing platform. Sens. Actuators B Chem. 2018, 267, 533-541. [CrossRef]

325. Chu, Z.; Peng, J.; Jin, W. Advanced nanomaterial inks for screen-printed chemical sensors. Sens. Actuators B Chem. 2017, 243, 919-926. [CrossRef]

326. Wu, X.; Song, Y.; Yan, X.; Zhu, C.; Ma, Y.; Du, D.; Lin, Y. Carbon quantum dots as fluorescence resonance energy transfer sensors for organophosphate pesticides determination. Biosens. Bioelectron. 2017, 94, 292-297. [CrossRef]

327. Wang, R.; Wang, X.; Sun, Y. One-step synthesis of self-doped carbon dots with highly photoluminescence as multifunctional biosensors for detection of iron ions and pH. Sens. Actuators B Chem. 2017, 241, 73-79. [CrossRef]

328. Garg, B.; Bisht, T. Carbon nanodots as peroxidase Nanozymes for biosensing. Molecules 2016, 21, 1653. [CrossRef] [PubMed]

329. Wang, Z.; Dai, Z. Carbon nanomaterial-based electrochemical biosensors: An overview. Nanoscale 2015, 7, 6420-6431. [CrossRef]

330. Revenga-Parra, M.; Villa-Manso, A.M.; Briones, M.; Mateo-Martí, E.; Martínez-Periñán, E.; Lorenzo, E.; Pariente, F. Bioelectrocatalytic platforms based on chemically modified nanodiamonds by diazonium salt chemistry. Electrochim. Acta $2020,357$. [CrossRef] 
331. Zhang, B.T.; Zheng, X.; Li, H.F.; Lin, J.M. Application of carbon-based nanomaterials in sample preparation: A review. Anal. Chim. Acta 2013, 784, 1-17. [CrossRef] [PubMed]

332. Briones, M.; Petit-Domínguez, M.D.; Parra-Alfambra, A.M.; Vázquez, L.; Pariente, F.; Lorenzo, E.; Casero, E. Electrocatalytic processes promoted by diamond nanoparticles in enzymatic biosensing devices. Bioelectrochemistry 2016, 111, 93-99. [CrossRef]

333. Hwang, H.S.; Jeong, J.W.; Kim, Y.A.; Chang, M. Carbon nanomaterials as versatile platforms for biosensing applications. Micromachines 2020, 11, 814. [CrossRef] [PubMed]

334. Rasheed, T.; Bilal, M.; Nabeel, F.; Adeel, M.; Iqbal, H.M.N. Environmentally-related contaminants of high concern: Potential sources and analytical modalities for detection, quantification, and treatment. Environ. Int. 2019, 122, 52-66. [CrossRef]

335. Sarkar, A.; Sarkar, K.D.; Amrutha, V.; Dutta, K. An overview of enzyme-based biosensors for environmental monitoring. In Tools, Techniques and Protocols for Monitoring Environmental Contaminants; Brar, S.K., Hegde, K., Pachapur, V.L., Eds.; Elsevier: Amsterdam, The Netherlands, 2019; pp. 307-329; ISBN 9780128146798.

336. Darwesh, O.M.; Ali, S.S.; Matter, I.A.; Elsamahy, T.; Mahmoud, Y.A. Enzymes immobilization onto magnetic nanoparticles to improve industrial and environmental applications. In Methods in Enzymology; Kumar, C.V., Ed.; Elsevier: Amsterdam, The Netherlands, 2020; Volume 630, pp. 481-502. ISBN 9780128201435.

337. Meng, Y.; Li, W.; Pan, X.; Gadd, G.M. Applications of nanozymes in the environment. Environ. Sci. Nano 2020, 7, 1305-1318. [CrossRef]

338. Justino, C.; Duarte, A.; Rocha-Santos, T. Recent Progress in Biosensors for Environmental Monitoring: A Review. Sensors 2017, 17, 2918. [CrossRef] [PubMed]

339. Solhi, E.; Hasanzadeh, M.; Babaie, P. Electrochemical paper-based analytical devices (ePADs) toward biosensing: Recent advances and challenges in bioanalysis. Anal. Methods 2020, 12, 1398-1414. [CrossRef]

340. Nigam, V.K.; Shukla, P. Enzyme Based Biosensors for Detection of Environmental Pollutants-A Review. J. Microbiol. Biotechnol. 2015, 25, 1773-1781. [CrossRef]

341. Wuana, R.A.; Okieimen, F.E. Heavy Metals in Contaminated Soils: A Review of Sources, Chemistry, Risks and Best Available Strategies for Remediation. ISRN Ecol. 2011, 2011, 1-20. [CrossRef]

342. Masindi, V.; Muedi, K.L. Environmental Contamination by Heavy Metals. In Heavy Metals; Saleh, H., Aglan, R., Eds.; InTech: London, UK, 2018; ISBN 978-1-78923-361-2.

343. Nomngongo, P.N.; Ngila, J.C.; Nyamori, V.O.; Songa, E.A.; Iwuoha, E.I. Determination of Selected Heavy Metals Using Amperometric Horseradish Peroxidase (HRP) Inhibition Biosensor. Anal. Lett. 2011, 44, 2031-2046. [CrossRef]

344. Md Meftaul, I.; Venkateswarlu, K.; Dharmarajan, R.; Annamalai, P.; Megharaj, M. Pesticides in the urban environment: A potential threat that knocks at the door. Sci. Total Environ. 2020, 711, 134612. [CrossRef] [PubMed]

345. Palma, P.; Palma, V.L.; Matos, C.; Fernandes, R.M.; Bohn, A.; Soares, A.M.V.M.; Barbosa, I.R. Assessment of the pesticides atrazine, endosulfan sulphate and chlorpyrifos for juvenoid-related endocrine activity using Daphnia magna. Chemosphere 2009, 76, 335-340. [CrossRef]

346. Gonçalves, C.; Alpendurada, M.F. Assessment of pesticide contamination in soil samples from an intensive horticulture area, using ultrasonic extraction and gas chromatography-mass spectrometry. Talanta 2005, 65, 1179-1189. [CrossRef] [PubMed]

347. Svane, S.; Sigurdarson, J.J.; Finkenwirth, F.; Eitinger, T.; Karring, H. Inhibition of urease activity by different compounds provides insight into the modulation and association of bacterial nickel import and ureolysis. Sci. Rep. 2020, 10, 8503. [CrossRef] [PubMed]

348. Li, M.; Cheng, X.; Guo, H. Heavy metal removal by biomineralization of urease producing bacteria isolated from soil. Int. Biodeterior. Biodegrad. 2013, 76, 81-85. [CrossRef]

349. Wang, T.; Wang, S.; Tang, X.; Fan, X.; Yang, S.; Yao, L.; Li, Y.; Han, H. Isolation of urease-producing bacteria and their effects on reducing $\mathrm{Cd}$ and $\mathrm{Pb}$ accumulation in lettuce (Lactuca sativa L.). Environ. Sci. Pollut. Res. 2020, 27, 8707-8718. [CrossRef]

350. Dalkıran, B. Amperometric determination of heavy metal using an HRP inhibition biosensor based on ITO nanoparticlesruthenium (III) hexamine trichloride composite: Central composite design optimization. Bioelectrochemistry 2020, 135, 107569. [CrossRef]

351. Nayak, S.; Kale, P. Inhibition assays of horseradish peroxidase by hexavalent chromium and other heavy metals. Int. J. Environ. Anal. Chem. 2020, 1-13. [CrossRef]

352. Ghica, M.E.; Carvalho, R.C.; Amine, A.; Brett, C.M.A. Glucose oxidase enzyme inhibition sensors for heavy metals at carbon film electrodes modified with cobalt or copper hexacyanoferrate. Sens. Actuators B Chem. 2013, 178, 270-278. [CrossRef]

353. Aponte, H.; Meli, P.; Butler, B.; Paolini, J.; Matus, F.; Merino, C.; Cornejo, P.; Kuzyakov, Y. Meta-analysis of heavy metal effects on soil enzyme activities. Sci. Total Environ. 2020, 737, 139744. [CrossRef]

354. Antonious, G.F. Enzyme activities and heavy metals concentration in soil amended with sewage sludge. J. Environ. Sci. Health Part A 2009, 44, 1019-1024. [CrossRef]

355. Tang, J.; Zhang, L.; Zhang, J.; Ren, L.; Zhou, Y.; Zheng, Y.; Luo, L.; Yang, Y.; Huang, H.; Chen, A. Physicochemical features, metal availability and enzyme activity in heavy metal-polluted soil remediated by biochar and compost. Sci. Total Environ. 2020, 701, 134751. [CrossRef]

356. Wiatrowska, K.; Wiatrowska, K.; Komisarek, J.; Dłużewski, P. Effects of heavy metals on the activity of dehydrogenases, phosphatases and urease in naturally and artificially contaminated soils. J. Elem. 2015. [CrossRef]

357. Jaworska, H.; Lemanowicz, J. Heavy metal contents and enzymatic activity in soils exposed to the impact of road traffic. Sci. Rep. 2019, 9, 19981. [CrossRef] 
358. Turdean, G.L. Design and Development of Biosensors for the Detection of Heavy Metal Toxicity. Int. J. Electrochem. 2011, 2011, 1-15. [CrossRef]

359. Amine, A.; Mohammadi, H.; Bourais, I.; Palleschi, G. Enzyme inhibition-based biosensors for food safety and environmental monitoring. Biosens. Bioelectron. 2006, 21, 1405-1423. [CrossRef] [PubMed]

360. Medeiros, A.; Maria, L.; Farias, A. Biosensor for Environmental Applications. In Environmental Biosensors; Sormeset, V., Ed.; InTech: London, UK, 2011; ISBN 978-953-307-486-3.

361. Pal, P.; Bhattacharyay, D.; Mukhopadhyay, A.; Sarkar, P. The Detection of Mercury, Cadium, and Arsenic by the Deactivation of Urease on Rhodinized Carbon. Environ. Eng. Sci. 2009, 26, 25-32. [CrossRef]

362. Domínguez-Renedo, O.; Alonso-Lomillo, M.A.; Ferreira-Gonçalves, L.; Arcos-Martínez, M.J. Development of urease based amperometric biosensors for the inhibitive determination of $\mathrm{Hg}$ (II). Talanta 2009, 79, 1306-1310. [CrossRef] [PubMed]

363. Özkara, A.; Akyil, D.; Konuk, M. Pesticides, Environmental Pollution, and Health. In Environmental Health Risk-Hazardous Factors to Living Species; Larramendy, M.L., Soloneski, S., Eds.; InTech: London, UK, 2016; ISBN 978-953-51-2402-3.

364. Rodriguez-Mozaz, S.; Marco, M.P.; Lopez De Alda, M.J.; Barceló, D. Biosensors for environmental applications: Future development trends. Pure Appl. Chem. 2004, 76, 723-752. [CrossRef]

365. Becker, J.M.; Ganatra, A.A.; Kandie, F.; Mühlbauer, L.; Ahlheim, J.; Brack, W.; Torto, B.; Agola, E.L.; McOdimba, F.; Hollert, H.; et al. Pesticide pollution in freshwater paves the way for schistosomiasis transmission. Sci. Rep. 2020, 10, 3650. [CrossRef]

366. Xiang, H.; Cai, Q.; Li, Y.; Zhang, Z.; Cao, L.; Li, K.; Yang, H. Sensors Applied for the Detection of Pesticides and Heavy Metals in Freshwaters. J. Sens. 2020, 2020, 1-22. [CrossRef]

367. Rajangam, B.; Daniel, D.K.; Krastanov, A.I. Progress in enzyme inhibition based detection of pesticides. Eng. Life Sci. 2018, 18, 4-19. [CrossRef] [PubMed]

368. Sassolas, A.; Prieto-Simón, B.; Marty, J.-L. Biosensors for Pesticide Detection: New Trends. Am. J. Anal. Chem. 2012, 3, $210-232$. [CrossRef]

369. Gothwal, A.; Beniwal, P.; Dhull, V.; Hooda, V. Preparation of Electrochemical Biosensor for Detection of Organophosphorus Pesticides. Int. J. Anal. Chem. 2014, 2014, 1-8. [CrossRef] [PubMed]

370. Kaur, J.; Singh, P.K. Enzyme-based optical biosensors for organophosphate class of pesticide detection. Phys. Chem. Chem. Phys. 2020, 22, 15105-15119. [CrossRef] [PubMed]

371. Badawy, M.E.I.; El-Aswad, A.F. Bioactive paper sensor based on the acetylcholinesterase for the rapid detection of organophosphate and carbamate pesticides. Int. J. Anal. Chem. 2014, 2014, 1-8. [CrossRef] [PubMed]

372. Mee-Hie Cho, C.; Mulchandani, A.; Chen, W. Functional analysis of organophosphorus hydrolase variants with high degradation activity towards organophosphate pesticides. Protein Eng. Des. Sel. 2006, 19, 99-105. [CrossRef] [PubMed]

373. Senko, O.; Stepanov, N.; Tyutyunov, A.; Sterlin, S.; Grinberg, V.; Makhlis, T.; Efremenko, E. Intensification of Organophosphorus Hydrolase Synthesis by Using Substances with Gas-Transport Function. Appl. Sci. 2017, 7, 1305. [CrossRef]

374. He, Y.; Du, J.; Luo, J.; Chen, S.; Yuan, R. Coreactant-free electrochemiluminescence biosensor for the determination of organophosphorus pesticides. Biosens. Bioelectron. 2020, 150, 111898. [CrossRef] [PubMed]

375. Jain, M.; Yadav, P.; Joshi, A.; Kodgire, P. Advances in detection of hazardous organophosphorus compounds using organophosphorus hydrolase based biosensors. Crit. Rev. Toxicol. 2019, 49, 387-410. [CrossRef]

376. Du, D.; Chen, W.; Zhang, W.; Liu, D.; Li, H.; Lin, Y. Covalent coupling of organophosphorus hydrolase loaded quantum dots to carbon nanotube/Au nanocomposite for enhanced detection of methyl parathion. Biosens. Bioelectron. 2010, 25, 1370-1375. [CrossRef] [PubMed]

377. Sánchez-Paniagua López, M.; Redondo-Gómez, E.; López-Ruiz, B. Electrochemical enzyme biosensors based on calcium phosphate materials for tyramine detection in food samples. Talanta 2017, 175, 209-216. [CrossRef]

378. Arduini, F.; Cinti, S.; Scognamiglio, V.; Moscone, D. Nanomaterials in electrochemical biosensors for pesticide detection: Advances and challenges in food analysis. Microchim. Acta 2016, 183, 2063-2083. [CrossRef]

379. Kurbanoglu, S.; Erkmen, C.; Uslu, B. Frontiers in electrochemical enzyme based biosensors for food and drug analysis. TrAC Trends Anal. Chem. 2020, 124. [CrossRef]

380. Zheng, Y.; Liu, Z.; Jing, Y.; Li, J.; Zhan, H. An acetylcholinesterase biosensor based on ionic liquid functionalized graphene-gelatinmodified electrode for sensitive detection of pesticides. Sens. Actuators B Chem. 2015, 210, 389-397. [CrossRef]

381. Ma, L.; He, Y.; Wang, Y.; Wang, Y.; Li, R.; Huang, Z.; Jiang, Y.; Gao, J. Nanocomposites of Pt nanoparticles anchored on UiO66-NH2 as carriers to construct acetylcholinesterase biosensors for organophosphorus pesticide detection. Electrochim. Acta 2019, 318, 525-533. [CrossRef]

382. Sun, Y.; Duan, N.; Ma, P.; Liang, Y.; Zhu, X.; Wang, Z. Colorimetric Aptasensor Based on Truncated Aptamer and Trivalent DNAzyme for Vibrio parahemolyticus Determination. J. Agric. Food Chem. 2019, 67, 2313-2320. [CrossRef] [PubMed]

383. Bilgi, M.; Ayranci, E. Biosensor application of screen-printed carbon electrodes modified with nanomaterials and a conducting polymer: Ethanol biosensors based on alcohol dehydrogenase. Sens. Actuators B Chem. 2016, 237, 849-855. [CrossRef]

384. Bekmezci, S.A.; Soylemez, S.; Yilmaz, G.; Udum, Y.A.; Yagci, Y.; Toppare, L. A new ethanol biosensor based on polyfluorene-gpoly(ethylene glycol) and multiwalled carbon nanotubes. Eur. Polym. J. 2020, 122, 109300. [CrossRef]

385. Samphao, A.; Kunpatee, K.; Prayoonpokarach, S.; Wittayakun, J.; Švorc, L'.; Stankovic, D.M.; Zagar, K.; Ceh, M.; Kalcher, K. An Ethanol Biosensor Based on Simple Immobilization of Alcohol Dehydrogenase on $\mathrm{Fe}_{3} \mathrm{O}_{4} @ \mathrm{Au}$ Nanoparticles. Electroanalysis 2015, 27, 2829-2837. [CrossRef] 
386. Maleki, N.; Kashanian, S.; Maleki, E.; Nazari, M. A novel enzyme based biosensor for catechol detection in water samples using artificial neural network. Biochem. Eng. J. 2017, 128, 1-11. [CrossRef]

387. Anatolievich, A.; Alekseevich, A.; Sergeevich, K.; Sergeevna, L. Device for Determining the Content of Glucose, Lactate, Ethanol and Starch in the Joint Presence. RU175461U1, 5 December 2017. Available online: https:/ / patents.google.com/patent/RU17546 $1 \mathrm{U} 1 /$ en?oq=RU175461U1 (accessed on 16 November 2020).

388. Wu, S.; Wang, Y.; Duan, N.; Ma, H.; Wang, Z. Colorimetric Aptasensor Based on Enzyme for the Detection of Vibrio parahemolyticus. J. Agric. Food Chem. 2015, 63, 7849-7854. [CrossRef] [PubMed]

389. Lu, L.; Tiantian, M.; Jingru, L.; Xugang, D. Photonic Crystal Heavy Metal Sensor with Immobilized Enzyme and Preparation Method Thereof. CN110865074A, 6 March 2019. Available online: https://patents.google.com/patent/CN110865074A/en?oq= CN110865074A (accessed on 16 November 2020).

390. Honggui, W.; Ya, Z.; Zhifeng, Z. A Kind of Preparation Method of Magnetic Carbon Tube-Molybdenum Disulfide Nano Enzyme and Its Method for Detecting Hydrogen Peroxide, Glucose. CN109387508A, 26 February 2019. Available online: https: / / patents.google.com/patent/CN109387508A/en?oq=CN109387508A\%2c+2018 (accessed on 16 November 2020).

391. Chauhan, N.; Maekawa, T.; Kumar, D.N.S. Graphene based biosensors-Accelerating medical diagnostics to new-dimensions. J. Mater. Res. 2017, 32, 2860-2882. [CrossRef] 